\title{
Discrimination and the Effects of Drug Testing on Black Employment
}

\author{
Abigail Wozniak \\ University of Notre Dame, NBER and IZA
}

January 2012

\begin{abstract}
Nearly half of U.S. employers test job applicants and workers for drugs. I use variation in the timing and nature of drug testing regulation to study discrimination against blacks related to perceived drug use. I find evidence of widespread discrimination against blacks in the absence of drug testing. Adoption of pro-testing legislation increases the share of blacks working in the testing sector by 7 to $30 \%$ and relative wages by $1.4-12.0 \%$, with the largest shifts among low skilled black men. Results suggest that employers substitute white women for blacks in the absence of testing.
\end{abstract}

(JEL Codes: J7, J15, K2, K3, M5)

Acknowledgements:

I thank Princeton University and the Upjohn Institute for financial support and Reed College for research space during the writing of this paper. I am particularly indebted to Shawn Moulton for his outstanding research assistance throughout this project and Lars Lefgren for helpful conversations. I also thank Giselle Kolenic and Michael Jones for their excellent work at different stages. Melissa Kearney, Jesse Shapiro, and seminar participants at the University of Notre Dame, the University of Connecticut, UC-Irvine, UC-Davis, Portland State University, and University of Oregon commented on early versions and thereby greatly improved the paper. I thank Bill Evans, Daniel Hungerman, Kasey Buckles, seminar participants at the University of Colorado-Denver, and three anonymous referees for comments that improved this version of the paper. All errors are my own. Author contact: a_wozniak@nd.edu. 


\section{Introduction}

In 2011, the United States entered the fifth decade of its War on Drugs. ${ }^{1}$ The drug war has been vilified both within the US and abroad, and it is often declared a failure, as in the face of these efforts drug use has risen over the period. ${ }^{2}$ Perhaps the most frequent charge is that the drug war has had disproportionately negative impacts on African Americans. This is certainly the case, and a large body of scholarship provides evidence affirming this claim. ${ }^{3}$ A quiet companion to the drug war has been the increased use of drug testing within mainstream American society. U.S. employers began requiring drug tests of their employees and job applicants on a large scale in the 1980s. Drug tests are now routinely required of job applicants and employees. ${ }^{4}$ In a comprehensive 1994 report on workplace drug testing, the National Research Council remarked that "[i]n a period of about 20 years, urine testing has moved from identifying a few individuals with major criminal or health problems to generalized programs that touch the lives of millions of citizens." (National Research Council, 1994, p. 180). According to the U.S. Department of Health and Human Services, 45\% of employees in the U.S. now work for firms that conduct some form of drug testing (see Appendix Table A1), while 15-20\% report having been tested themselves (Fendrich and Kim, 2002).

Contrary to what one might expect, the rise of employer drug testing may have provided a means for African-Americans to escape some of the drug war's disproportionate impacts. Even as the drug war linked blacks with drug use in the popular imagination, drug testing provided a means for non-using blacks to prove their status to employers. In this paper, I model and test for the impact of employer drug testing on labor market outcomes for blacks. I incorporate drug testing by

\footnotetext{
1 The phrase "War on Drugs" was first used by Richard Nixon in 1971.

${ }^{2}$ For example, see the introductory chapters of Provine (2007) and Baum (1997). Jimmy Carter's New York Times Op-Ed from June 17, 2011, used the anniversary of the War on Drugs to call it a failed policy.

${ }^{3}$ For thorough studies, see Western (2006), Provine (2007), and Alexander (2010).

${ }^{4}$ Drug tests are also commonly required of military recruits and personnel, and as a pre-requisite for participation in school activities (Mehay and Pacula 1999; U.S. Supreme Court decision in Vernonia v. Acton 1995; "At One College, A Fight Over Required Drug Tests," New York Times, October 10, 2011. The New York Times also reports that threequarters of states have recently considered a drug test requirement for some benefits. At least four have passed. ("States Adding Drug Test as Hurdle for Welfare." October 10, 2011.)
} 
firms and drug use by workers into a Roy model with signaling. The model allows the information in drug tests to impact hiring and reduce ex ante bias through one of two channels. The first is a standard statistical discrimination channel, in which testing provides employers with more information on blacks than whites. The second is updating of biased beliefs about use rates across the two groups. I derive three implications for how drug testing would impact sorting into testing and non-testing sectors across race and drug use groups. I cannot distinguish the two channels theoretically, but I discuss facts that suggest biased beliefs cannot be ruled out in the conclusion.

To test the model's predictions, I combine data from the National Survey on Drug Use and Health - both public use and special tabulations of confidential data - and the Current Population Surveys. I also estimate a set of Mincer-style equations that allow returns to race and other characteristics to differ according to an individual's exposure to testing. Using three decades of microdata, I examine changes in outcomes within and across demographic groups and industries as drug testing prevalence increased nationally. I identify employer drug testing's impacts using state and year variation in statutes affecting the ability of employers to test both job applicants and employees. Importantly, such statutes have taken both "pro-testing" and "anti-testing" forms. These contrasting statutes provide a useful check, since the estimated impacts should be different in the two groups of states when compared with non-adopting states. I also exploit differences across metropolitan areas within states in the likelihood of drug testing based on stable differences in industrial and firm size structure, both of which are strong correlates of drug testing.

Consistent with the model's predictions, I find that employment of non-users increased in testing industries following the advent of drug testing. I find suggestive evidence that this increase was more pronounced for blacks, which is consistent with ex ante bias. Using state-level variation in the timing and nature of drug testing legislation, I find large labor market impacts for blacks, a fact which is also consistent with widespread ex ante bias. The results are largest for low skilled black 
men. Specifically, pro-testing legislation increases the share of low skilled black men working in high testing industries by $7-10 \%$ relative to all states with no such law and by up to $30 \%$ relative to states with an anti-testing law. I find similar increases in their coverage in group health and pension plans, benefits which are associated with the larger and more sophisticated firms that are also more likely to test, and in employment of low skilled black men at large firms generally. Finally, I find that wages for this group increase by $3-4 \%$ relative to states with no pro-testing law and by $12 \%$ relative to antitesting states. This wage increase is driven by the employment shifts into larger firms and industries with known wage premia. Results from anti-testing states suggest that employers substitute white women for blacks in the absence of testing.

This paper has important implications for our understanding of labor market discrimination, and these in turn have implications for how to address it. First, the model is more flexible than canonical statistical discrimination models. ${ }^{5}$ In it, employers operate without racial animus, conditional on their beliefs, but these beliefs may be based either in racially biased impressions or in differential information quality on the two racial groups. This allows a type of discrimination that is very close to the implicit discrimination described in Bertrand et al. (2005). This feature is also consistent with evidence from other social sciences and with new evidence from experimental economists. Sociologists and political scientists have both long argued that certain behaviors can become "racialized"- that is, disproportionately associated with a particular group. Beckett et al. (2005) and Gilens 1996 are examples. More recently, Albrecht et al. (2011) find that participants in a laboratory labor market experiment fail to fully update beliefs about individual productivity when this is revealed subsequent to learning that individuals belong to groups with different levels of

\footnotetext{
${ }^{5}$ Charles and Guryan (2008 and 2011) provide a useful overview of the main models of labor market discrimination and discuss challenges to testing these models. For detailed analyses of statistical discrimination models, see Aigner and Cain (1977); Lundberg and Startz (1983); Altonji and Pierret (2001); and Oettinger (1996).
} 
average productivity. ${ }^{6}$ I find evidence consistent with this model, and therefore consistent with ex ante bias in black hiring in the testing sector. I cannot distinguish empirically between ex ante bias arising from racially biased beliefs and that arising from classic statistical discrimination. However, I find a large role for bias in hiring that is not purely taste-based. It suggests an opportunity for improving black outcomes by improving employer information about black job applicants.

A second contribution is that - in contrast to most studies on discrimination - this paper evaluates a specific, current policy that policymakers can easily extend or encourage. Research on employer drug testing has so far been limited to studying specific industries or firms where testing has been implemented (Mas and Morantz (2008); Carpenter (2007); Jacobson (2003); Mehay and Pacula (1999); Lange et al. (1994)). These early studies were important for understanding effects in these industries, but they overlook the possible general equilibrium effects of such a widespread policy. Moreover, none of this earlier work examines differential impacts across racial groups.

Finally, this paper adds to the set of studies that directly examines employer responses to changes in the information they receive. These include Holzer et al (2006); Stoll and Bushway (2008); Finlay (2009); and Autor and Scarborough (2008). The first three focus on the impact of criminal background information on hiring of ex-offenders and blacks. Autor and Scarborough (2008) examine the impact of a skills test on minority hiring into low skill service jobs, and find that the test increases precision of worker selection (more productive workers are hired) but that the racial composition of hiring is unchanged. They conclude that in this sector, human-based screening was unbiased relative to the skills test. This paper shows that policies that encourage employer drug testing led to economically large increases in black employment at firms that are more likely to test. This suggests that the Autor and Scarborough results may be unique to their setting and that biased screening on other dimensions may be widespread.

\footnotetext{
${ }^{6}$ Fehrshtman and Gneezy (2001) also find that subjects rely on incorrect stereotypes (biased beliefs) and pay a price for it in a trust game.
} 


\section{Background on Drug Use, Drug Testing, and Drug Testing Statutes}

\section{A. The Expansion of Employer Drug Testing}

The arrival of drug testing in the labor market in the early 1980s was driven by a combination of three factors: a small number of somewhat sensational workplace accidents in which drugs were alleged to have played a role; the development of accurate and relatively inexpensive screening devices; and rising public anxiety over the prevalence of drugs in society. These culminated in the creation of federal incentives for workplace drug testing. ${ }^{7}$ The early 1980 s were a period in which small numbers of employers, albeit often large ones, began requiring drug tests of their employees in an atmosphere of legal uncertainty. Litigation by tested employees was common. In 1987, Ronald Reagan signed an executive order requiring that federal agencies adopt testing to establish “drug free workplaces." The 1988 Drug Free Workplace Act went further, requiring that federal contractors adopt comprehensive anti-drug policies. Employee and applicant drug testing was clearly in the spirit of this legislation. By the late 1980s, the grounds on which employers could require testing was well-established in the courts, notably with a major Supreme Court decision in 1989 (National Research Council, 1994, Appendix B). Thus, the late 1980s constitute a turning point after which employers begin implementing drug testing programs in increasing numbers.

Recognizing the increasing prevalence of these tests, the Bureau of Labor Statistics (BLS) conducted a survey in 1988 to gauge the extent of drug testing practices among U.S. employers (U.S. Department of Labor, 1989). The findings of the report are summarized in Table 1, in the column headed "1988." A follow up to the BLS survey was conducted by outside researchers in 1993 (Hartwell, et. al. 1996). The findings of that report are summarized in the column headed "1993." The first point to take from Table 1 is that regularities in testing prevalence appear in both surveys. Larger employers are more likely to test than smaller employers; there is wide variation in rates of

\footnotetext{
${ }^{7}$ Facts in this paragraph are taken from Tunnell (2004), Ch. 1; National Research Council (1994) Ch. 6 and Appendix A. A shorter review of the history of employer testing can be found in Knudsen et al. (2003). See Baum (1997) for an excellent history of the drug war.
} 
testing across industries; and there is regional variation, with larger shares of establishments testing in the South and Midwest than in the Northeast or West. Knudsen et al. (2003) found similar differences across industries and firm size categories using a 1997 phone survey of employed respondents. The second point to take away from Table 1 is that the share of testing employers increased dramatically in the period between the surveys. Direct comparisons across the industry and region cells are complicated by changes in the sampled universe across the surveys. ${ }^{8}$ However, the share of establishments with 50 or more employees testing in 1988 was 0.16 (Hartwell et al. 1996). This rose to 0.48 by 1993, or a three-fold increase for this group overall.

There has been no follow up to the 1993 survey, but comparable statistics can be computed using the annual National Survey on Drug Use and Health (NSDUH). The NSDUH questioned respondents about the drug testing policies of their employers starting in 1997. I calculated the shares of employed respondents replying that their employer practiced some form of drug testing. The final column of Table 1 reports these shares overall and by industry. ${ }^{9}$ The NSDUH shares indicate that drug testing increased only modestly in the period following the 1993 BLS survey. The rapid expansion of employer drug testing therefore appears to have ended by the second half of the 1990s with testing stabilized at its new, higher level.

\section{B. State Level Drug Testing Laws}

During the late 1980s, individual states also began to pass guidelines regulating the use of testing by employers (DeBernardo and Nieman, 2006; National Research Council, 1994). The statelevel legislation grew out of the opposing forces at work behind the federal laws and legal history: the desire to punish and criminalize drug use on the one hand, and concerns for privacy and civil

\footnotetext{
${ }^{8}$ In the 1993 survey, the sample was limited to establishments with 50 or more employees. Since small employers are much less likely to test (as is obvious in the 1988 figures), increases in the shares of testing employers by industry and region are driven in part by this sample adjustment.

9 The BLS surveys omitted establishments in the agriculture and government sectors. Industry testing rates can be calculated for these in the NSDUH.
} 
liberties protection on the other. ${ }^{10}$ Both sets of concerns generated legislation at the state level. Some states enacted explicitly "pro" employer testing legislation, while others enacted explicitly "anti" legislation. Broadly, pro-testing legislation provided incentives for employer testing (often through rebates on UI or worker's compensation insurance), capped certain liabilities for testing employers, or explicitly permitted certain types of testing. Anti-testing legislation explicitly limited the types of testing employers could require.

I rely on DeBernardo and Nieman (2006) for details of the variation in state-level drug testing policies. Their 2006-2007 Guide to State and Federal Drug Testing Laws is a resource for employment law professionals, and they categorize states as either pro- or anti-testing. Twenty-one states are categorized. The remainder is considered neutral on employer drug testing. Fourteen states are classified as pro-testing; seven are anti-testing. More detail on their classification is provided in Appendix Table A1. Table A1 shows that while pro-testing states are more commonly found in the South, there is still considerable variation within regions. For example, Ohio is a Northern Rust Belt state, but it is also pro-testing. Utah and Montana are both inter-mountain West states but Utah adopted pro-testing legislation while Montana adopted anti-testing laws. I follow DeBernardo and Nieman in classifying states as pro, anti, or neutral on employer drug testing. They do not assign a date in which a state "became" pro- or anti-testing, but they provide a complete listing of statutes related to their classification along with dates of passage. I use the year a related statute was first adopted as the "start year" for a state's employer drug testing stance.

It is difficult to demonstrate the effect of these laws empirically, since data on employer testing prevalence at the state level is nearly non-existent. However, upon special request, the agency that conducts the NSDUH survey (The Substance Abuse and Mental Health Services Administration, or SAMHSA, within Health and Human Services) agreed to tabulate respondent

\footnotetext{
${ }^{10}$ It is unclear from the available social history whether employers as a group were in favor of drug testing.
} 
answers to questions about employer drug testing at the state level for the periods 2002-2003 and 2007-2009 and provide them in a table for public circulation. It is not possible to obtain comparable tabulations for earlier periods, since only very recent waves of the NSDUH were designed to be representative at the state level. During the period 2002 to 2009, three states adopt pro-testing laws and three adopt anti-testing laws. Table 2 shows levels of reported employer drug testing during the two periods for which the data were tabulated.

There are three points to take from this table. First, there are large levels differences across the three groups of states in the prevalence of reported testing. Respondents in pro-testing states report the highest rates of testing and those in anti-testing state report the least. Respondents in protesting states report that their employer tests at rates 50 to $73 \%$ higher than those in anti-testing states. See Appendix Table A1 for more detail on cross-state differences in testing. A second point is that testing of all forms increased in all state groups over 2002-2009. In fact, the increase was largest among the unclassified states that form the control group for a large portion of the empirical analysis. Therefore results from analysis relying on comparisons between pro-testing and unclassified states will be attenuated as drug testing becomes more common in policy-neutral states. Finally, the level increases in testing shares were smaller in anti-testing states than in either the pro-testing or unclassified group. In percentage terms, these increases were even smaller for specific types of testing - drug tests in the hiring process and random drug tests - that are more likely to be the subject of anti-testing regulations. In the case of random testing, the increase was also smaller in percentage terms in anti-testing states as compared to pro-testing states.

The anti-testing laws therefore appear to have curtailed the use of testing by employers in the anti-testing states. The data also suggest that pro-testing laws work to increase the use of testing by employers within a state. The level change in reported employer testing in pro-testing states increased from 50.8 to 54.8 percent over the period. This was a smaller level (and percentage) 
increase than in the unclassified states, but it was in the expected direction for the hypothesized "first stage." Moreover, testing rates in unclassified states still fall well short of those in pro-testing states, even in the early years of the period, despite the fact that testing is not regulated or illegal in any of the former. This suggests that the high rates of testing observed for pro-testing states in 2002-03 are in part due to the passage of pro-testing laws prior to 2002.

\section{Drug Testing and Drug Use}

Drug tests are characterized by high rates of false negatives as well as timing that is frequently predictable. ${ }^{11}$ Nevertheless, many individuals fail them. One of the only sources of public information on drug test failure rates is Quest Diagnostics, a medical testing company that is one of the nation's largest suppliers of drug test kits and urinalysis services. Quest publishes drug test positivity rates from its labs in their annual Drug Testing Index. The index makes several points, in spite of its non-representativeness. First, the number of tests performed in the U.S. annually is very large. Quest reported conducting 8.4 million tests in 2007, and this only represents a share of all tests performed nationally. Second, the overall failure rate in Quest labs was 3.8\% in 2007, with slightly higher rates among job applicants (as opposed to testing of current employees) and in jobs where testing was not federally mandated for safety reasons (Quest Diagnostics, 2008). There is also considerable geographic variation in failure rates, with the worst-performing county groups in Quest data reporting failure rates in the range of $5.5-16 \%$ in 2007 . There is evidence that drug test failure typically stems from regular use. DuPont et al. (1995) estimate that a majority of those testing positive in random workplace tests are daily users while only $7 \%$ are infrequent, annual users.

In contrast to the limited data on drug testing by employers, measures of drug use are available back to 1979 in the NSDUH. For most of the survey's history, blacks and whites have

\footnotetext{
11 More details on testing and failure channels are available in Appendix I.
} 
reported drug use at nearly identical rates. There is some variation in drug type, with blacks reporting more marijuana use and whites more "hard" drugs, but overall, the rate of any reported drug use in the past month is very similar for blacks and whites. Over the $1990-2006,13 \%$ of whites and $12 \%$ of blacks reported some drug use in the past month in the NSDUH. This holds even within gender and skill groups, with less skilled blacks and less skilled whites (no college education) both reporting past month use at rates of $19 \%$. This is consistent with evidence in Kaestner (1999). More detail on use and reporting patterns can be found in the Appendix I.

More importantly for the purposes of this paper, there is a large body of evidence showing that the perception is that blacks use drugs at much higher rates than whites. In a thorough study of such perceptions and their consequences, Beckett et al. (2005) conclude that racial drug arrest disparities cannot be solely attributed to either structural differences in drug use or to policing tactics that are otherwise race-neutral. Rather, they argue that police have developed a set of perceptions around who was likely to be carrying drugs and that these perceptions led them to disproportionately target blacks. They write, "[P]opular discussions and images of the "crack epidemic" in the 1980s appear to... continue to shape both popular and police perceptions of drug users (emphasis added)." The fact that even those responsible for investigating and documenting drug crime can hold perceptions of use that differ from reality suggests that others might also hold persistent misperceptions. Several studies support this possibility. In a survey of hiring managers, Wozniak (2011) documents a belief that blacks are more likely to fail a drug test. Burston et al. (1995) cite evidence that even black youth overestimate their own drug use relative to whites. They also cite a 1989 survey in which 95\% of respondents described "the typical drug user" as black. 


\section{A Roy Model of the Employment Effects of Industry Drug Testing}

In this section, I incorporate drug use by workers and drug testing by firms into a standard, two-sector Roy model as developed in Heckman and Sedlacek (1985) and Heckman and Honore (1990). Let firms be divided into the testing sector and the non-testing sector, so named because of the practices they will adopt when drug testing becomes available. Workers are endowed with a vector of sector-specific skills $\mathbf{s}=\left(\mathrm{s}_{\mathrm{T}}, \mathrm{s}_{\mathrm{N}}\right)$, denoting skills in the testing and non-testing sectors, respectively. Workers can apply for employment in either sector and move between them costlessly at any time. There are two periods, or equilibria: the pre-testing period, when drug testing is not available to firms, and the post-testing period, in which all testing firms instantaneously adopt testing of all workers and job applicants.

The key modification I make to the standard Roy model is to assume that testing sector skills are negatively affected by a worker's drug use. For simplicity, I assume that drug use reduces testing sector skills to zero, so that $\mathbf{s}$ becomes the following:

$$
s=\left(s_{T}, s_{N} ; D_{i}\right)=\left(\left\{\begin{array}{c}
s_{T} \text { if } D_{i}=0 \\
0 \text { if } D_{i}=1
\end{array}, s_{N}\right)\right.
$$

Skills s are observable, and I assume that drug use is independent of $\mathbf{s} .{ }^{12}$ Testing sector firms anticipate that the total output from hiring a given set of workers—some of whom use drugs—is lower than it would be if there was no drug use. Assume for now that firms have no information about which hires are more likely to use drugs. In this case, they simply deflate offered wages by a constant probability of drug use. Thus testing sector firms offer wages $w_{T}$ equal to an applicant's expected marginal productivity given the possibility of drug use, $p: w_{T}=k_{T}(1-p) s_{T}$ where

\footnotetext{
${ }^{12}$ I discuss this and the assumption that drug use sets productivity in the testing sector to zero in detail in Appendix III.
} 
$k_{T}(1-p)=\pi_{T}(p){ }^{13}$ Non-testing firms offer wages equal to expected (and realized) marginal productivity: $w_{N}=\pi_{N} S_{N}$ where $\pi_{N}$ is a constant. $\pi_{T}(p)$ and $\pi_{N}$ are then the sector-specific skill prices in a standard Roy model.

I assume that skills in the two sectors are log-normally distributed, with $\ln s_{j} \sim N\left(\mu_{j}, \sigma_{j}\right)$ so that $\ln s_{j}=\mu_{j}+\varepsilon_{j}$ for $\mathrm{j}=\mathrm{T}, \mathrm{N} .^{14}$ Assuming workers choose their sector of employment to maximize wages, the probability of employment in the testing sector is equal to the probability that the testing sector wage exceeds the non-testing sector wage, which in turn becomes a function of the parameters of the skill distribution:

$$
\begin{aligned}
& \operatorname{Pr}(T)=\operatorname{Pr}\left(\pi_{T}(p) s_{T} \geq \pi_{N} s_{N}\right)= \\
& \quad \operatorname{Pr}\left(\ln k_{T}+\ln (1-p)+\mu_{T}+\varepsilon_{T} \geq \ln \pi_{N}+\mu_{N}+\varepsilon_{N}\right)
\end{aligned}
$$

Note that a worker's own drug use does not affect the wages he expects to receive in either sector since only population drug use is relevant for wage setting in the testing sector.

Suppose that in addition to $\mathbf{s}$ and $\mathrm{D}_{\mathrm{i}}$, workers possess an observable characteristic $\mathrm{M}_{\mathrm{i}}$ which takes the values 0 and 1 . Now there are two populations of workers. In principle $\mathrm{M}$ can be any observable characteristic, but for exposition let $\mathrm{M}=1$ represent blacks and $\mathrm{M}=0$ represent whites. The distribution of $\mathbf{s}$ does not vary across the $\mathrm{M}$ groups. ${ }^{15}$

Now consider firms' beliefs about rates of drug use in the two demographic groups. Denote these $p_{M 1}$ and $p_{M 0}$. These may differ from true rates of use, denoted $p_{M 1}^{*}$ and $p_{M 0}^{*}$. Without loss of generality, assume $p_{M 1}>p_{M 0}$. This implies that firms' productivity expectations are unequal across groups, even if firms believe the underlying skills distributions are the same, i.e. absent drug use.

\footnotetext{
13 This assumes that total output is a function of the sum of individual worker productivities and does not otherwise depend on their combination. $k_{T}$ is a constant return to skill in the testing sector that is discounted by $p$ to give the traditional sector-specific skill prices in the Roy model.

${ }^{14}$ Heckman and Honore (1990) show that the main results of the (log-normal) Roy model are robust to the less restrictive assumption of $\log$ concavity in $\varepsilon_{T}-\varepsilon_{N}$.

15 See Autor and Scarborough (2008) for a discussion of evidence that the variance of productivity does not differ empirically across racial groups. They make the same assumption about variance in their model. The assumption that the mean of productivity is invariant across groups can be relaxed.
} 
Firms in the testing sector will therefore offer higher wages to whites $(M=0)$ than they will to blacks $(\mathrm{M}=1)$, conditional on $\mathrm{s}_{\mathrm{T}}$. Using the formula in (2), it is clear that these differences in assumed use rates imply that $\operatorname{Pr}\left(T \mid \boldsymbol{s}, M_{i}=1\right)<\operatorname{Pr}\left(T \mid \boldsymbol{s}, M_{i}=0\right)$ in the pre-testing period.

Drug testing introduces a signal into this environment. Following what is known about the validity of drug tests, I assume that firms that require drug tests of their applicants receive a signal $t_{i}$ of drug use with the following properties ${ }^{16}$ :

$$
\begin{aligned}
& t_{i}=1 \Rightarrow D_{i}=1 \\
& t_{i}=0 \Rightarrow E\left[D_{i} \mid \text { post testing }\right]=\tilde{p}
\end{aligned}
$$

This type of signal potentially accomplishes two things. First, it increases the precision of employer beliefs about drug use among workers. This means that $\tilde{p}<p$. In the Theory Appendix, I demonstrate that this holds under certain conditions. Second, the information that arrives via the signals may enable employers to revise their beliefs about drug use rates.

Increased precision in worker screening raises the likelihood that non-users are employed in the testing sector. To see this, first notice that $\tilde{p}<p$ implies that $\pi(\tilde{p})>\pi(p)$. The introduction of testing raises $\pi_{T}(p)$ in Equation 2 and leaves all other terms unchanged, unambiguously increasing $\operatorname{Pr}(T) .{ }^{17}$ Therefore the probability of employment in the testing sector rises among nonusers after testing is introduced.

This increase in precision need not affect blacks and whites differentially. For example, if $p_{M 1}=p_{M 0}$ and $\tilde{p}_{M 1}=\tilde{p}_{M 0}$, then testing sector employment will rise equally for blacks and whites after the introduction of testing. Autor and Scarborough (2008) show this more generally in a somewhat different model. As long as employer beliefs are relatively unbiased for blacks and whites,

${ }^{16}$ These are consistent with low rates of false positives and high rates of false negatives in the drug screens commonly used by employers.

${ }^{17}$ See Theory appendix for CDF formula. For users, the effect of testing on the probability of employment in the testing sector is actually ambiguous, as shown in the Theory Appendix. 
then the added precision of testing can change who is hired from each group while leaving overall group hiring rates unchanged. However, if testing affects the precision of firms' ex ante beliefs differentially, then testing may change relative outcomes across the two demographic groups.

A change in relative outcomes following the introduction of testing would be consistent with ex ante bias in employer beliefs about drug use, but the nature of the change in relative precision is important for the interpretation of this bias. There are two possibilities. First, employers may have believe their black applicants use drugs at rates equal to the true average, $p_{M 1}=p_{M 1}^{*}$, but because of better information about white applicants, they believe use among the white applicants they consider is lower than average, $p_{M 0}<p_{M 0}^{*}$. In this case, the ex ante bias corresponds to classic statistical discrimination. Employers have more precise information that allows them to screen out some white drug users but no black users. The introduction of testing may then improve information on black applicants relative to whites. On the other hand, employers may hold biased beliefs about black drug use rates, such that $p_{M 1}>p_{M 1}^{*}$ but $p_{M 0}=p_{M 0}^{*}$. Then testing also has the potential to reduce the disparity between perceived and actual use rates for blacks. The interpretation, however, is different. In this case, the ex ante bias is driven by inaccurate employer rather than informational disparities. I cannot distinguish between the two types of bias empirically. In both cases, employer updating means that $p_{M 1}-p_{M 1}^{*}>\tilde{p}_{M 1}-p_{M 1}^{*}$. Substitution of the new employer beliefs into (2) shows that the probability of employment in the testing sector rises for blacks after testing is introduced. The revision of ex ante bias would also lead to larger changes in $\pi(p)$ for blacks than for whites, so that the probability of testing sector employment increases more for black non-users than for white non-users. ${ }^{18}$

In sum, the model generated three predictions that I will test empirically. First, the share of non-users employed in the testing sector should increase after the advent of testing, regardless of

\footnotetext{
${ }^{18} \mathrm{It}$ is important to note that this assumes that (relative) drug use rates are unchanged across demographic groups, but the evidence in Appendix Table A2 suggests this is a reasonable assumption.
} 
employer bias in beliefs about drug usage. Second, if employers' beliefs about drug use are overstated for blacks relative to whites (ex ante bias of either kind), then the increase in testing sector employment should be greater among black non-users than white non-users. Finally, if employers are ex ante biased, testing should increase the employment of blacks in the testing sector. I discuss the two possible interpretations of ex ante bias in light of the results in the conclusion.

\section{Assessing the Impact of Employer Drug Testing: Data and Empirical Models}

\section{A. Microdata Sources}

I draw on microdata from two sources. The bulk of the analysis uses microdata on individuals ages 18 to 55 from the IPUMS versions of the March Current Population Surveys (King et al. 2010). I use this data to answer questions about differential impacts of employer drug testing on labor market outcomes without regard to drug use. For example, were blacks more likely to be hired into the testing sector after testing became widespread? The March CPS surveys contain the richest set of employment variables in the monthly CPS. The resulting data set includes representative, annual cross sections of prime aged individuals in the U.S. spanning 1980 to 2010.

I supplement the CPS analysis with data from the National Survey on Drug Use and Health (NSDUH). The NSDUH is a nationally representative survey of individuals aged 12 and older. It is currently conducted annually although the survey was semi-annual between 1987 and its inception in 1979. The sample size has increased considerably over time. The 1979 sample contained roughly 7200 individuals and grew to include over 55,000 individuals in 2006. It is the definitive source of data on drug use in a representative US population. The NSDUH contains detailed information on respondent drug use histories and, in later years, on employer drug testing practices. I use the NSDUH data to answer questions about how the sorting of drug users and non-users changed across sectors as testing expanded. All NSDUH analysis and statistics are unweighted. 
Unfortunately, causal analysis of testing's impacts on labor market outcomes in the NSDUH sample are limited by two features of the survey. First, it does not include geographic identifiers below the nine Census divisions. This precludes the difference-in-differences analysis I carry out in the CPS using state-year variation in drug testing legislation. ${ }^{19}$ Second, it is not possible to construct exact hourly wages from NSDUH data as income information is only available in bins. Descriptive statistics for the NSDUH sample are available upon request.

Descriptive statistics on the CPS sample are given in Table 3. Race/ethnicity is measured using indicators for Black and Hispanic. ${ }^{20}$ Education is measured using two categories: high school dropouts and high school graduates (the low skill group) and those with any post-secondary education (the high skill group). Table 3 also summarizes employment outcomes of interest. Because the CPS does not ask about employer drug testing, I use three proxies for employment at a likely testing firm. The first is a dummy for employment in the high testing sector. I define the high testing sector as one-digit industries that achieve a testing rate of over $50 \%$ by the late 1990 s according to Table 1. Specifically, these are mining; communications and utilities; transportation; manufacturing; and government. ${ }^{21}$ Table 3 shows that the high testing sector employs about $30 \%$ of currently employed workers. The second is the dummy variable for employment at a very large firm (> 500 employees), which is only available for 1988 onwards. As discussed above, there is a clear relationship between employer size and the likelihood of drug testing. About $40 \%$ of the total sample is employed in a very large firm. The final measure is a dummy indicating coverage in a group health or pension plan. ${ }^{22}$ These benefits are likely related to employer size and

\footnotetext{
${ }^{19}$ Carpenter (2007) has carefully documented correlations between an individual's outcomes and the reported drug testing practices of her employer.

${ }^{20}$ Other non-white races are not separately identified in the CPS until the latter part of my sample period. As a result, the omitted race/ethnicity category in most specifications is properly called "whites, Asians and Native Americans," although I refer to the group simply as "whites."

${ }^{21}$ The universe for the industry variable is actually workers who worked at any time in the last five years. I limit this to workers who were employed at the time of the survey.

22 The universe of the group health questions changed over time, and the question wording changed slightly. However, results are similar when pension coverage alone is the dependent variable.
} 
sophistication—e.g. the presence of a well-developed human resources department. The benefits coverage outcome is also interesting because it reflects a broader notion of job quality than wages alone. Table 3 shows that coverage rates for both benefits are somewhat higher than $50 \%$. Hourly wages are constructed by dividing wage and salary income earned last year by the product of weeks worked last year and usual weekly hours. Wages are adjusted to 1990 levels using the CPI-U.

Table 3 also breaks out various subsamples of interest. In addition to the means for the full sample period (overall mean), the table shows means for the eight years prior to the Workplace Drug Act as well as separately for the subgroup of states that ever adopt either form of drug testing legislation. Table 3 also presents means for the dependent variables by racial subgroups for all periods. One can also compare the characteristics of CPS respondents from states that ultimately become pro- or anti-testing. Since I exploit variation within states over time, identification does not require that the two groups of states look identical. Nevertheless, the two groups of states are largely balanced on the dimensions in Table 3. The main exceptions are racial composition and prevalence of employment at the largest firms. Since several Southern states are pro-testing, this group has a much larger share of blacks in their populations than do anti-testing states.

\section{B. Estimating Equations}

I will first assess the model's prediction that the share of non-users employed in the high testing sector should increase after the introduction of testing. To do this, I estimate a model with employment in a high testing industry as the dependent variable using the NSDUH data. However, since the NSDUH contains limited geographic information, I cannot exploit state-year variation in employer drug testing statutes. Instead, I identify the impact of expanded employer drug testing using time series variation in national rates of testing combined with information on regional differences in drug testing rates from Appendix Table A1. Data limitations force me to restrict the 
NSDUH data to the 1985 to 1997 waves. I divide the period into three phases: the pre-testing years of 1985 to 1988, the period of rapid transition to higher testing rates of 1989 to 1994, and the postperiod of 1994 to 1997. I then divide the nine Census divisions (the finest geographic information available in the public NSDUH) into low, intermediate, and high testing based on division-level average testing rates calculated from Appendix Table A1 and noted in Table 4.

I then look for evidence of two phenomena. First, were non-users increasingly sorted into high testing industries over time and in higher testing regions? And second, was the shift of nonusers into testing sector employment larger for blacks? A regression with high testing industry on the left hand side would require examining multiple triple (drug use $\mathrm{x}$ time period $\mathrm{x}$ testing region) and quadruple interactions (the triple interaction times race) to test predictions one and two. An alternative is to examine differences in adjusted high testing sector employment rates between users and non-users by time period-testing region cells. I regression adjust high testing sector employment using controls for demographics (age, race, Hispanic ethnicity, sex, and educational attainment), demographic group-specific cubic time trends, group-specific division fixed effects, and all relevant main effects. I then compute the difference in means within the nine region by time period cells, subtracting the mean residual high testing sector employment of users from that for non-users. This approach is more descriptive than a regression but also more transparent. ${ }^{23}$

I then turn to the CPS to examine the impact of state-level employer drug testing laws on relative labor market outcomes. The following equation allows the employer testing environment in an individual's state to affect the returns to her personal characteristics and generates difference-indifferences estimates of drug testing's impacts by demographic group (or DDD estimates):

$$
y_{i s t}=\operatorname{Pro}_{s t} \Gamma_{i s t}^{\prime} \beta_{1}+\tilde{\Gamma}_{i s t}^{\prime} \beta_{2}+\beta_{3} \operatorname{Pro}_{s t}+\Theta_{s}+\Theta_{t}+\Theta_{s} t+\varepsilon_{i s t}
$$

\footnotetext{
${ }^{23}$ Results from an equivalent regression model available upon request. A final issue with the regression approach is the need to correct standard errors for the small number of clusters - in this case, at most nine.
} 
$\mathrm{Pro}_{s t}$ is an indicator variable equal to 1 if state $s$ with a pro-testing classification in DeBernardo and Nieman (2006) has enacted drug testing legislation by year $t . \beta_{1}$ and $\beta_{2}$ are $\mathrm{k} \times 1$ vectors of (demographic) group-specific coefficients. $\Gamma$ is a $\mathrm{k} \mathrm{x} 1$ vector of demographic characteristics. These include indicators for black, white, and Hispanic ethnicity; gender; age less than 25; and no postsecondary education (low skill). $\tilde{\Gamma}$ is identical to $\Gamma$ except that age is entered directly and age-squared is included. The specification includes a typical set of DD controls when the policy variation is at the state and year level. These are state fixed effects, $\Theta_{s}$; year fixed effects, $\Theta_{t}$; and state time trends. The state fixed effects absorb permanent differences across states in the outcome variable, while the year fixed effects absorb common shocks to outcomes at the national level. The state-specific time trends absorb smooth changes in labor market outcomes across states over the period of the study. $\mathrm{y}_{\text {ist }}$ is one of several possible labor market outcomes. These include the three proxies for employment at a likely testing firm described above. I also examine the impact of testing legislation on employment in general and on log wages, although both are outside the scope of the model. The estimates of interest are the coefficients in the $\beta_{1}$ vector. These show how log wages and the four employment variables change differentially for the demographic groups in $\Gamma$ after a state adopts protesting legislation. Therefore these are triple differenced, or DDD, estimates.

Although Equation 5 is a common specification, it is likely inadequate for studying differential impacts of time-varying, state-level policies across demographic groups. For one thing, there are likely fixed group-specific differences across states in the outcome variable. There are also likely important changes that are common to the U.S. labor market for a demographic group as a whole over this period. An example is rising wage inequality, which increased differentially for workers according to race, gender, and skill group. ${ }^{24}$ One might also control directly for changing state labor

\footnotetext{
${ }^{24}$ Katz and Murphy (1992). Autor, Katz and Kearney (2008) show that the major changes in the U.S. wage structure that occurred over the 1980s and 1990s are fairly well-approximated by group specific quadratics.
} 
market conditions as well as state level drug enforcement efforts, which might proxy for anti-drug sentiment in the state. The following ideal specification would address all these concerns:

$$
\begin{gathered}
y_{i s t}=\operatorname{Pro}_{s t} \Gamma_{i s t}{ }^{\prime} \beta_{1}+\tilde{\Gamma}_{i s t}{ }^{\prime} \beta_{2}+\beta_{3} \operatorname{Pro}_{s t}+\chi_{s t}{ }^{\prime} \beta_{4}+ \\
\Theta_{s}+\Theta_{s} \Gamma_{i s t}{ }^{\prime}+\Theta_{t}+\Theta_{t} \Gamma_{i s t}{ }^{\prime}+\Theta_{s} t+\Theta_{s} t^{2}+\Theta_{s} t^{3}+\mu_{i s t}
\end{gathered}
$$

To arrive at (5), three main changes were made to the basic specification in (4). Groupspecific state effects and group-specific year effects were added to the main effects for these categories. Time varying state-level controls were added $\left(\chi_{\text {st }}\right)$. These are the state unemployment rate, state minimum wage, and state incarceration rate. ${ }^{25}$ The first two control for variation in state labor market conditions that does not follow a smooth trend. The state incarceration rate is a proxy for intensity of state-level efforts to curb drug trafficking, which may have affected drug use and perceptions of use independently of employer testing policies. Finally, linear state trends were replaced with state-specific cubic time trends.

Estimating Equation 5 is possible but imposes two limitations. First, estimation of models with group-specific state and year effects is time consuming because of the large number of parameters. Second, the data series on state-level incarceration rates I obtained is only available through 2004, so this limits the years of data that can be included in the analysis. Therefore, I adopt the following as the preferred specification for most estimates in the paper:

$$
\begin{gathered}
y_{i s t}=\operatorname{Pro}_{s t} \Gamma_{i s t}{ }^{\prime} \beta_{1}+\tilde{\Gamma}_{i s t}{ }^{\prime} \beta_{2}+\beta_{3} \operatorname{Pro}_{s t}+\Theta_{s}+\Theta_{s} \Gamma_{i s t}{ }^{\prime}+ \\
t+t^{2}+t^{3}+t \Gamma_{i s t}{ }^{\prime}+t^{2} \Gamma_{i s t}{ }^{\prime}+t^{3} \Gamma_{i s t}{ }^{\prime}+\Theta_{s} t+\Theta_{s} t^{2}+\Theta_{s} t^{3}+\mu_{i s t}
\end{gathered}
$$

As I show later, the parameter estimates of interest are unaffected by using group-specific cubic trends in place of the group-specific year effects. This speeds computation considerably. Also, estimates are unaffected by the exclusion of the $\chi_{\text {st }}$ controls and consequent addition of the 2005-

${ }^{25}$ State level unemployment rates for 1976-2009 are from the Bureau of Labor Statistics. State minimum wage data for 1969-2010 are from the Department of Labor. State prison populations for 1977-2004 are from the Bureau of Justice Statistics. 
2010 data. I will also show that several estimates of interest are affected by moving from the parsimonious specification (4) to the more sophisticated model in (5).

Because the nature of drug testing legislation varied across states, I am able to expand the specification in (6) to further exploit the variation in testing environments provided by states that adopted anti-testing laws. In the specification below, $A n t i_{s t}$ is a scalar that takes the values zero or one according to timing of legislation in states classified as anti-testing. The controls are the same, and the specification becomes the following (main effects for state effects and the time cubic are omitted for readability):

$$
\begin{gathered}
y_{i s t}=\operatorname{Pro}_{s t} \Gamma_{i s t}{ }^{\prime} \beta_{1}+\tilde{\Gamma}_{i s t}{ }^{\prime} \beta_{2}+\beta_{3} \operatorname{Pro}_{s t}+A n t i_{s t} \Gamma_{i s t}{ }^{\prime} \beta_{4}+\beta_{5} A n t i_{s t}+ \\
\Theta_{s} \Gamma_{i s t}{ }^{\prime}+t \Gamma_{i s t}{ }^{\prime}+t^{2} \Gamma_{i s t}{ }^{\prime}+t^{3} \Gamma_{i s t}{ }^{\prime}+\Theta_{s} t+\Theta_{s} t^{2}+\Theta_{s} t^{3}+\mu_{i s t}
\end{gathered}
$$

Now there are two sets of DDD estimates: $\beta_{1}$ as before but also $\beta_{4}$. If employer drug testing changes employment outcomes differentially across demographic groups (and if state testing laws affect employer behavior), then $\beta_{1}$ and $\beta_{4}$ should generally be of opposing signs. This additional variation allows me to test whether the content - and not just the presence - of legislation matters.

Finally, I exploit differences across local labor markets within states in the likelihood of exposure to testing. These differences arise because industrial structure and the distribution of firm sizes varies across metropolitan areas within a state, but these differences are quite stable over time. The composition of the local economy therefore creates differences in the likelihood than an individual was exposed to drug testing but does not itself respond to the adoption of testing legislation. I collected metropolitan area level information on the distribution of firm size and industrial composition and created an index of exposure to drug testing by multiplying the elements of these distributions by the national shares of reported testing by industry and firm size. ${ }^{26} \mathrm{I}$

${ }^{26}$ Data on MSA-level employment by firm size and industry for 1997-1999 were taken from the U.S. Census Bureau's Statistics of U.S. Businesses. I calculate the index of drug testing exposure for MSA $j$ as follows: 
normalize the index to have mean zero and standard deviation one, and incorporate it into the

Equation 6 by replacing the first three terms in (6) with the first seven terms in (8):

$$
\begin{gathered}
y_{i s t}=\operatorname{Pro}_{s t} D T_{i s t} \Gamma_{i s t}{ }^{\prime} \gamma_{1}+\tilde{\Gamma}_{i s t}{ }^{\prime} \gamma_{2}+\gamma_{3} \text { Pro }_{s t}+\gamma_{4} D T_{i s t}+D T_{i s t} \Gamma_{i s t}{ }^{\prime} \gamma_{5}+ \\
\gamma_{6} \operatorname{Pro}_{s t} D T_{i s t}+\operatorname{Pro}_{s t} \Gamma_{i s t}{ }^{\prime} \gamma_{7}+\text { remaining terms from }(6)+\eta_{i s t}
\end{gathered}
$$

Here, the estimates of interest are in the vector $\gamma_{1}$. These show whether relative outcomes change differentially for individuals in metropolitan areas with high drug testing exposure $\left(\mathrm{DT}_{\mathrm{ist}}\right)$ as compared to individuals in the same demographic group and state but in areas with lower exposure. These estimates provide a final check on whether differential changes in labor market outcomes after the adoption of state-level testing laws are related to the likelihood of experiencing testing.

All models are estimated using OLS. Therefore coefficients are from a linear probability model for several outcomes. This facilitates the calculation of total impacts across interactions and main effects. Since the means of all dependent dummy variables are well inside the unit interval, the results are very similar when estimated via probit. In all estimates using CPS data, standard errors are clustered at the state level. However, the linear probability model allows calculation of multilevel clustered standard errors. The results are robust to clustering on state and year instead of state only.

\section{Results}

Before moving to estimation of the empirical models, I present preliminary evidence on the impact of state-level employer drug testing policies using a simple event study analysis. I examine only one outcome - employment in a high testing industry - for the sake of conciseness. Figure 1

$$
\rho_{j}=\left(\sum_{k} \delta_{j k} r_{k}\right)+\left(\sum_{m} \delta_{j m} r_{m}\right)
$$

$k$ indicates industries and $m$ indicates firm size categories. The $\delta$ terms represent the share of $j$ 's employment in a particular industry or firm size category. These sum to 1 within area $j$. The $r$ terms are the national level rates of employers in the various categories engaging in drug testing. These rates are taken from the sources in Table 1. Theoretically, the index can achieve a maximum value of 2, if all employers in all categories are testing, but I normalize the measure to have mean zero and standard deviation one. 
shows that the prevalence of this employment declined steadily over the entire data period for both blacks and whites. Consistent with the means in Table 3, blacks are more likely than whites to work in the high testing sector. The question for an event study, then, is not what happened to trends in testing sector employment as laws were phased in over time, but rather what happened to relative employment trends for blacks versus whites around the point at which a law was introduced?

Figures $2 \mathrm{a}$ and $2 \mathrm{~b}$ answer that question. Each shows the difference between year zero and year $\mathrm{t}$ employment rates in high testing industries, where year zero is the year of adoption and $\mathrm{t}$ ranges from ten years prior to passage to ten years after. Smoothed trends in this difference are plotted separately for blacks and whites. In both panels, the trend for whites declines smoothly over time with no noticeable change in the year of passage. Consistent with Figure 1, the share of whites employed in high testing industries is declining over time. It appears unaffected by state employer drug testing laws. For blacks, however, trends in both pro- (2a) and anti-testing (2b) states show changes at year zero. In pro-testing states, the steady decline in testing sector employment among blacks stops at year zero and then reverses to tick upward slightly by several years after law passage. The change is less dramatic in anti-testing states, but there is still a clear inflection point for the black trend at year zero, indicating that the decline in black testing sector employment picked up speed in the year of and immediately following passage of an anti-testing law. Together, the two figures suggest that employer testing laws encouraged testing sector firms to employ blacks relative to whites in pro-testing states while anti-testing laws discouraged it. To test this more formally, I turn to the empirical analysis.

\section{A. The Impact of Testing on the Sorting of Users and Non-Users into Employment Sectors}

Table 4 tests the first of the model's predictions: that the share of non-users employed in the testing sector increases after the introduction of testing. Panel (i) of Table 4 shows that the 
probability of adjusted high-testing sector employment was insignificantly different for users and non-users in all three regions during the pre-testing period. A respondent is classified as a drug user if she reports using any drug illicitly in the past month and as a non-user otherwise. ${ }^{27}$ During the transition period, the difference in testing sector employment widens, with non-users becoming 4 to 6 percentage points more likely to work in the high-testing sector than users. For the two higher testing regions, this gap persists and retains significance into the post-testing period. However, the gap disappears in the low testing region. As shown in Appendix Table A1, many low testing states passed anti-testing laws starting in the transition years. This potentially explains the roll back of the earlier effect. Panels (ii) and (iii) show that this pattern is similar for blacks and whites, with the exception that the non-user employment advantage is only significant for blacks in the two higher testing regions in the post-testing period.

This evidence affirms the model's first prediction: users sort increasingly into high testing sector employment in times and places where testing is more common. This also confirms that drug testing provides employers with information that they use in making their hiring decisions.

To assess the model's second prediction, I consider the change in the testing sector employment gap between users and non-users separately for blacks and whites. For both groups, the gap widens in favor of non-users during the transition period. The gap widens further for blacks in the post-testing period but is largely stable for whites. Also, the increase in the gap over the preperiod in the highest testing region is larger for blacks than for whites. I conclude that the evidence in Table 4 is therefore suggestive that the impacts of employer drug testing were larger and more positive for non-using blacks than non-using whites.

\section{B. The Impact of Testing on Relative Labor Market Outcomes in the CPS}

${ }^{27}$ Results are similar when users are defined as those reporting any drug use in the past year, zero otherwise. 
The remainder of the analysis uses variation in state drug testing legislation to generate DDD estimates of the impact of testing on relative labor market outcomes. Results from the preferred specification, Equation 6, are shown in Table 5. Here the control group is comprised of individuals in all states that have not affirmatively adopted a pro-testing law. This includes states that will eventually adopt pro-testing laws in the future, states that will or have adopted anti-testing laws, and all never-adopting states. The five columns report results from estimating Equation 6 with five different dependent variables.

The coefficients of interest are the interactions of demographic characteristics with the protesting law indicator. Blacks, Hispanics, women, and the low skilled all have consistently signed impacts of pro-testing legislation on the three measures of high testing sector employment. For blacks and the low skilled, the impacts are positive and of similar magnitude, showing increases of 1 to 3 percentage points in the dummies for high-testing industry employment, large firm employment, and benefits coverage. For blacks, the positive impacts on benefits coverage and on large firm employment are significant at the $0.1 \%$ and $5 \%$ levels respectively. Log wages also increase for blacks following the adoption of a pro-testing law. The impacts on these measures are also positive for the low skilled but of about half the magnitude, with the exception of a statistically significant positive wage impact of 1.3 percent that is similar to the 1.4 percent increase for blacks. Impacts for the young (18-25) and Hispanics are generally very small economically and all are insignificant. There is no impact on overall employment for any group. Taken together, these results suggest that blacks experience larger and more consistent improvements in testing sector employment and wages following the adoption of a pro-testing law than any other group.

For women, on the other hand, the impacts of pro-testing legislation are uniformly negative. High testing industry employment, large firm employment, and benefits coverage all decline for women by about 1.5 percentage points - a change that closely mirrors the improvements for blacks. 
The point estimate on log wages is also negative for women. The bottom rows of the table show that post-estimation tests of equality reject that the coefficients for blacks and women are the same for all measures except the employment dummy. In other words, pro-testing legislation has significantly different impacts on blacks and women.

Before moving on from Table 5, it is worth noting that the reported additional covariates generally perform as expected. These will not be reported in subsequent tables. However, while there are no big surprises in the bottom half of the table, there is some important heterogeneity. Specifically, the significant determinants differ across the three proxies for testing sector employment. The low skilled, for example, are significantly more likely to work in a high-testing industry than the high skilled, but they are significantly less likely to work in a very large firm or receive benefits. This and the other differences across the bottom half of the columns in Table 5 suggest that the proxies for testing sector employment each capture something slightly different, which makes them useful as a set of related but not identical outcomes.

Equation 7 incorporates the policy variation from anti-testing states, and estimates from this model are presented in Table 6. The top panel shows that estimates on the pro-testing $x$ demographic group interactions from Table 5 are robust to the addition of the anti-testing interactions. In fact, the point estimates and patterns of significance are essentially unchanged between Tables 5 and 6 for the pro-testing interactions. Nevertheless, the anti-testing interactions are interesting for several reasons. First, estimates for blacks are negative, economically large, and statistically significant for both hightesting industry employment and pension coverage. This suggests that the impact of pro-testing legislation on blacks is due directly to the increased adoption of testing by employers, since the passage of laws discouraging such testing leads to impacts on blacks that are nearly the perfect opposite. Importantly, t-tests reject the equality of the pro- and anti-testing interactions with black status for all three measures of testing sector employment and for wages, as shown in the bottom 
rows of the table. The negative impact of testing legislation on women appears to be confined to pro-testing states. There are no significant impacts - or even large point estimates - for anti-testing laws on women in Table 5. However, t-tests reject the equality of the pro- and anti-testing interactions with female status at the $10 \%$ level or better for all outcomes except general employment. Blacks and women in pro- and anti-testing states therefore experience significantly different impacts of the legislation in their respective states. These impacts differ not just across blacks and women in the same states, but also across blacks (or women) in the two types of states.

Sample and population size both likely play roles in the anti-testing estimates for blacks and women. First, as is obvious from the geographic variation in Appendix Table A1, anti-testing states tend to have small black populations whereas pro-testing states have larger ones. Fixed and constant-trend differences across these states are controlled in the estimates using fixed effects and state time trends, but it is still the case that state-level black populations in anti-testing states are very small. Therefore it is to be expected that point estimates for the black $x$ anti-testing interactions will have larger standard errors than estimates for the black $x$ pro-testing interactions. A related point is that in pro-testing states, an economically large shift in labor market outcomes for blacks may well have spillover effects to other groups, such as women, since blacks are a large share of the population in those states. This is less true in anti-testing states. Where blacks are a very small share of the population, then an economically large change for blacks may still have little impact on the labor market equilibrium as a whole. This may explain why there are strong negative impacts of employer testing on women in pro-testing states but no opposing effects in anti-testing states.

The interactions with Hispanic and anti-testing legislation in Table 6 are uniformly negative and economically large. However, the interactions with Hispanic are never significant, and t-tests do not reject that the interactions with Hispanic are equal across pro- and anti-testing states. If these laws do have an impact on Hispanics, I am not able to precisely estimate them with the available 
data. Therefore I exclude Hispanics from subsequent analysis in order to focus on the impacts for blacks and women.

To examine the separate contributions of race, skill, and gender from a different angle, I break down the black and white populations into the mutually exclusive demographic groups (listed in Appendix Table A2). The equations estimated in Table 7 substitute indicator variables for these eight groups for the Mincer-style controls for demographic characteristics used in Tables 5 and 6. I drop Hispanics from the sample and divide the remaining CPS respondents into categories according to race; sex; and skill. I modify Equation 2 to include indicators for the seven groups and their interactions with pro- and anti-testing legislation. High skilled white men are omitted. All other controls are modified to use the exclusive groups instead of the demographic controls in earlier specifications.

The impacts of pro-testing laws in Table 7 are even larger than in earlier specifications. This is because they combine the impacts of being black, male, and low skilled, for example, that were estimated "separately" in the Mincer-style specifications. Table 7 shows that it is low skilled blacks who experience the largest positive impacts of pro-testing legislation on their labor market outcomes. All point estimates are also positive for low skilled black women. I find that employment in the high testing sector increases by 3.8 to 4.5 percentage points for low skilled black men, relative to the same group in states that do not adopt a drug testing law. This is an increase of $9.7 \%$ for employment in a high testing industry and roughly 7-9\% for the other two outcomes. The magnitude is even larger when compared to low skilled black men in anti-testing states. Here the difference in testing sector employment is approximately 9 to 12 percentage points between blacks in pro- versus anti-testing states, as shown in the bottom rows of the table. This implies a relative increase in high testing sector employment of about 30\% for low skill blacks. The results also show a statistically and economically significant wage increase of $3.4 \%$ for low skill black men in pro- 
testing states. The difference relative to the same group in anti-testing states is even larger, at $12 \%$, and also statistically significant. For low skilled black men, I again reject that the interactions with pro- and anti-testing state status are the same for all outcomes except general employment.

The pro- versus anti-testing interactions are sometimes statistically unequal for women (both black and white), but for no other group are all three testing sector proxies unequal. Nevertheless, the general pattern identified in previous tables - in which impacts for white women are negative in pro-testing states and positive in anti-testing states - is also apparent in Table 7. Low skilled black men are also the only group in which the wage impacts of testing legislation are statistically different across the two groups of states, despite the significant coefficient on pro-testing legislation for low skilled white men in the wage equation.

In unreported results, I examined whether the wage increases observed for blacks in protesting states in Tables 6,7 , and 8 can be explained by the shifts into testing sector employment also documented in those tables. The testing sector has larger firms and includes manufacturing and transportation industries. All three are associated with well-known wage premia. To assess the role of increased testing sector employment in raising black wages, I added the three testing sector measures to the wage equations in Tables 5, 6, and 7. The addition of these controls greatly reduced the coefficients on pro-testing $\times$ black in Tables 5 and 6 . The coefficients were not statistically significant, and I could no longer reject equality of the coefficients for blacks and women (in Table 5) and blacks in pro-testing states versus anti-testing states (in Tables 6 and 7). I conclude that wage increases for blacks overall are largely explained by shifts into testing sector employment.

In Table 8, I add interactions for metropolitan area drug testing exposure to the specifications in Table 7. Because larger firms and firms in industries where testing is more common are more likely to test, and because the representation of such firms differs across metropolitan areas, I expect that the impacts of state drug testing laws may differ across metro areas within a state 
depending on their industry and firm size structures. As described above, I develop a simple index of testing exposure at the metropolitan area level based on data from 1997-1999. At the state level, for which I have data for a longer time period, industry and firm size composition are highly stable over time. I therefore assume that MSA-level firm size and industry structure is constant and exogenous to state drug testing laws. I treat MSA-level drug testing exposure as a fixed characteristic that may alter the impact of state level drug testing laws.

I also restrict the sample to early adopting states and to observations within three years of a state's adoption of drug testing legislation. I make these restrictions for several reasons. Most importantly, the problem of workers selecting into markets based on testing is likely more severe at the metropolitan area level than at the state level. It is much easier for workers to move between MSAs than across state and regional boundaries. This is the main motivation for imposing the three year restriction. This kind of arbitrage is more likely the more time has passed since the law change. Also, changes in MSA coding after 1999 make matching the industry and firm size composition data to the CPS microdata more challenging, although not impossible. ${ }^{28}$ This is the reason for restricting to 1999 and earlier. It is also worth noting that it is not clear we should expect MSA-level differences in industrial composition to fully explain the impacts of state-level drug testing laws across residents of different states. In other words, state drug testing policies may still have significant impacts even if MSA-differences in industrial composition are found to contribute significantly to these impacts.

The results are shown in Table 8. Coefficients on the interactions of MSA-level drug testing exposure with exclusive demographic groups are reported in the bottom panel. The results are in the second column are striking. These show that employment in high testing industries increased substantially more in high testing exposure MSAs for all black groups. The coefficients indicate the impact of moving up one standard deviation in the MSA drug testing exposure index for the

\footnotetext{
28 I have experimented with using the data for 2000-2006 in this exercise. The results are largely similar to those reported but often have larger standard errors, consistent with an increase in measurement error when matching the microdata from 2000-2006 to the metropolitan area characteristics based on older MSA codes.
} 
indicated demographic group in a pro-testing state. This is a large change in testing exposure, but the estimated changes are also large, in the range of 4.4 to 5.6 percentage points. Consulting Table 3 again, these impacts for high testing industry employment represent an increase of $13 \%$ or more over the mean. The pattern is less consistent for the other two measures of testing sector employment, but large firm employment and benefits coverage still show relative increases for several black groups in MSAs with higher testing exposure.

Consistent with the idea that the impact of state drug testing laws might not operate exclusively through the local composition of firm size and industry, the state level impacts in the top panel are still statistically significant for some combinations of demographic groups and outcomes. In particular, low skilled black men are more likely to have benefits coverage in states with a protesting law. This does not differ across high and low testing exposure MSAs (although there is a significant boost to high skilled black men in these outcomes in MSAs with high testing exposure).

The possibility of general equilibrium effects of migration make it difficult to attribute intrastate differences in outcomes under state-level drug testing laws solely to the likelihood of exposure to testing in different metropolitan areas. Yet in spite of these complications, the differences in employment outcomes across blacks in the same state but different MSAs is striking. The evidence in Table 8 is consistent with a strong positive impact of exposure to employer drug testing on the probability of black employment in high testing industries, particularly for low skilled black men.

\section{Robustness Analysis}

The potential for unobserved factors to drive policy impacts in a study of this design is always a concern. A simple way to test for the importance of these is to use a placebo data set - in which policy changes are randomly assigned - to re-estimate the main empirical models. For brevity, I focus on the specification in Column 2 of Table 7, which shows how high-testing industry 
employment was affected in states passing either a pro-testing law or an anti-testing law. I created a placebo data set in which states were randomly assigned law changes that match the true distribution of law changes over time and in pro-/anti-testing character. For example, three states passed protesting laws and one passed anti-testing legislation in 1999. In the placebo data, three states (from those not previously assigned in the round) will be randomly assigned a pro-testing law change and one an anti-testing law change in 1999.

I drew 1000 such sets of "placebo laws" and estimated the column 2, Table 7 specification on all of them. The results are plotted as a histogram in Figure 3. The x-axis shows the difference between the pro- and anti-testing interactions with black from the estimation and therefore gives the estimated pro- minus anti-testing state difference in high-testing industry employment for blacks. In other words, Figure 3 plots the effect size calculated in the bottom rows of Table 7 for each draw of the data. The placebo estimates center around zero, and the true estimate, indicated with a vertical line, is in the far right tail of the distribution. I therefore conclude that there is a strong basis for attributing causality to the policy changes in the main results. Note that the true law distribution will occasionally be drawn randomly, so it is not inconsistent with this conclusion to have some placebo estimates that are very similar to the true estimate, as happens in Figure 3.

I also examined the robustness of the main reported results to alternative control variable specifications. As discussed in Section IV, the specification in Tables 5 and higher differs from the simpler and more common specification in Equation 4. I compare estimates obtained from the preferred specification - in Equation 6 - to those from (4) by incrementally changing the control terms in (4) to match those in (6). This allows me to examine the importance of my choice of control variable specifications.

The results are shown in Appendix Table A3; more detailed discussion is provided below the table. I conclude that the inclusion of group-specific non-linear time controls is important for the 
relative results I obtain, but that the form in which these are included (as group-specific year effects or as cubic time trends) is not important. I further conclude that the point estimates I obtain for blacks are robust across a variety of specifications, although the relative magnitude of these estimates is somewhat sensitive to specification choice. Finally, Column 5 shows that the estimates are not sensitive to excluding the time-varying state-level controls, so I exclude them from the preferred specification in order to retain the years 2005-2010 in the analysis.

As a final check, I restrict the data to observations from 1990 and later. This has two advantages. First, it omits the major years of the crack epidemic and associated drug wars, which may have operated differentially over time and across states in a way that affected black employment patterns but is not fully captured by the controls. Second, it aligns the data period more closely with the years of prime law passage. The cost to this change is that pre-law trends may not be well estimated for many states, due to a shortened period between the start of the data and law passage. Appendix Table A4 reports the results of this exercise. For conciseness, I report only the results for the main Table 7 estimates of interest. For the most part, results from the main analysis in Table 7 are robust to this change in the data period. Overall employment for low skilled black men is still unaffected by state employer drug testing laws. Pro-testing laws increase the share of low skilled black men in high-testing industries and large firms relative to the same group in anti-testing states, and their relative wages also increase. The p-values are above conventional levels for the wage and high testing industry employment outcomes, but for large firm employment the difference is still statistically significant. The only result that does not hold up to the change is the positive impact on pension or health coverage. In Table A4, the difference in coverage for low skilled black men across the two groups of states is small, negative, and statistically insignificant. 


\section{Conclusions and Discussion}

This paper examined the impact of the development of widespread employer drug testing on relative employment outcomes for African Americans. I modeled the introduction of drug testing as a signal to employers in a Roy model of employment sector selection. The model showed that the impact of testing on black outcomes depends in part on employer beliefs about drug use across racial groups prior to testing. I used microdata from the National Survey on Drug Use and Health and the March Current Population Surveys to examine the impact of drug testing's expansion on black outcomes over a 30 year period.

The analysis generated several findings. First, the probability of employment in the testing sector rose markedly for non-users as testing expanded over time. In the early 1980s, self-reported non-users were not significantly more likely than drug users to work in high-testing industries. By the late 1990s, they were 4 to 8 percentage points significantly more likely to do so in regions with medium to high levels of employer drug testing. This suggests that the expansion of testing allowed employers to more reliably choose non-users from among potential workers. Moreover, this probability increased more for non-using blacks than for non-using whites in regions where testing was most common. Third, employment of blacks increased at testing sector firms following the adoption of pro-testing statutes at the state level. Estimates of the increase are particularly large for low skilled black men. Impacts for this group are economically large and equate to increases in testing sector employment of $7-10 \%$ for low skilled black men in pro-testing states relative to all other states or 30\% relative to all anti-testing states. Low skilled black men also experienced significant wage increases - of about $4 \%$ relative to all other states and $12 \%$ relative to anti-testing states- following the adoption of pro-testing laws. This wage increase can be explained by increased employment in the testing sector, which has larger firms in industries with well-known wage premia. 
Finally, I find some evidence that employers substitute white women for blacks in the absence of drug screening.

I conclude that these results are consistent with widespread discrimination against blacks by firms in the testing sector prior to the advent of drug testing. Because the information available via drug testing clearly impacted black hiring, the results are inconsistent with a taste based model of discrimination. In such models, racial animus is a fixed characteristic of market participants and cannot be influenced by information. This suggests that the ex ante bias arose either because employers had information about black drug use that was correct on average but imprecise relative to that for whites, or because they held beliefs about black drug use that were inaccurate relative to their beliefs about whites, on average.

It is tempting to side with the first of these - ex ante statistical discrimination - and rule out inaccurate beliefs as unlikely to persist in equilibrium. ${ }^{29}$ Nevertheless, three facts lead me to be more cautious. First, drug use rates rose over the 1990s for all groups, including blacks. If drug testing allowed employers to improve the precision of their employment screening for blacks relative to whites, then the costs of drug use would have increased for blacks relative to whites. This does not rule out the possibility that black drug use increased in the post-testing period, but if improved precision (reduced statistical discrimination) were important, it seems unlikely that black drug use would rise one-for-one with white drug use as the data show. Second, blacks were more likely than whites to be employed in the testing sector prior to the rise in testing. This casts some doubt on the statistical discrimination assumption that employers systematically had poor information about blacks relative to whites. Finally, as Charles and Guryan (2011) document, several models have demonstrated that taste-based discrimination can survive in a competitive market. If the profit opportunities from non-discriminating employers can be consistently passed up, it seems possible

${ }^{29}$ This would also be consistent with evidence of widespread statistical discrimination against blacks documented in Fryer et al. (2011). 
that the opportunities from refining deeply held beliefs can also be passed up in equilibrium. Ultimately, more work is needed to separately identify discrimination arising from behavioral factors like racialized beliefs versus that arising from informational disparities.

An ancillary lesson for labor economists is that employers care about drug use, drug test failure, or characteristics that drug test failure proxies (or all three). This research shows that the ability to screen their workforce for drug use provided employers with additional information beyond other observable characteristics. They clearly put this information to use in their hiring and retention decisions. This is consistent with other research indicating the importance of noncognitive skills for employment outcomes.

For policymakers, this research shows that - contrary to what many might expect - drug testing by employers has helped African Americans make inroads into testing industries since the late 1980s. This research suggests that testing improved blacks' access to jobs in large firms, with better benefits and higher wages. It is therefore possible that drug testing is in part responsible for the fact that blacks did not fare as badly as might have been expected in the decades of rapidly rising inequality (Card and Dinardo, 2002). Interestingly, Fendrich and Kim (2002) documented changes in worker attitudes toward testing that are consistent with the effects reported here. These authors collated public opinion poll data on drug testing from over twenty polls spanning 1985-1999. They found that public approval of employer drug testing has risen over time. However, this is driven by blacks, those with less than a high school education, and younger workers. Over the same period, approval declined among more educated and older workers. This suggests that these groups are aware of the benefits that testing has provided them. 


\section{References}

Aigner, Dennis J. and Glen G. Cain. 1977. "Statistical Theories of Discrimination in Labor Markets." Industrial and Labor Relations Review. 30(2): 175-187.

Altonji, Joseph G. and Charles R. Pierret. 2001. "Employer Learning and Statistical Discrimination." The Quarterly Journal of Economics. 116(1): 313-350.

Albrecht, Konstanze, Emma von Essen, Juliane Parys, and Nora Szech. 2011. "Updating, SelfConfidence, and Discrimination." IZA Discussion Paper 6203.

Alexander, Michelle. 2010. The New Jim Crow: Mass Incarceration in the Age of Colorblindness. New York, NY: The New Press.

Autor, David H. and Scarborough, David. "Does Job Testing Harm Minority Workers? Evidence from Retail Establishments." Quarterly Journal of Economics (February, 2008): 219-277.

Autor, David H., Lawrence F. Katz, and Melissa S. Kearney. 2008. Review of Economics and Statistics. 90(2): 300-323.

Baum, Dan. 1997. Smoke and Mirrors: America's War on Drugs and Politics of Failure. Back Bay Books.

Beckett, Katherine; Kris Nyrop; Lori Pfingst; and Melissa Bowen. 2005. "Drug Use, Drug Possession Arrests, and the Question of Race: Lessons from Seattle." Social Problems. 52(3): 418-441.

Bertrand, Marianne, Dolly Chugh, and Sendhil Mullainathan. 2005. "Implicit Discrimination." American Economic Review 95(2): 94-98.

Burston, Betty Watson; Dionne Jones; and Pat Roberson-Saunders. 1995. "Drug Use and African Americans: Myth versus Reality." Journal of Alcohol and Drug Education. 40(2): 19-39.

Card, David and John DiNardo. 2002. "Skill Biased Technological Change and Rising Wage Inequality: Some Problems and Puzzles.” Journal of Labor Economics. 20(4): 733-783.

Carpenter, Christopher. 2007. "Workplace Drug Testing and Worker Drug Use." Health Services Research. 42(2): 795-810.

Carter, Jimmy. "Call Off the Global Drug War." New York Times. Op-Ed. Section A, page 35. July 17, 2011.

Charles, Kerwin and Jonathan Guryan. 2008. "An Empirical Assessment of Becker's The Economics of Discrimination.” Journal of Political Economy. 116(5): 773-809.

Charles, Kerwin and Jonathan Guryan. 2011. "Studying Discrimination: Fundamental Challenges and Recent Progress.” NBER Working Paper \#17156.

Conference Board, The. "Corporate Experiences with Drug Testing Programs." Research Report No. 941 (1990).

De Bernardo, Mark A. and Matthew F. Nieman. 2006-2007 Guide to State and Federal Drug Testing Laws. $14^{\text {th }}$ Edition, Institute for a Drug-Free Workplace, 2006.

DuPont, Robert L.; David W. Griffin; Bernard R. Siskin; Sarah Shiraki; and Edward Katze. 1995. "Random Drug Tests at Work: The Probability of Identifying Frequent and Infrequent Users of Illicit Drugs.” Journal of Addictive Diseases. 14(3): 1-17.

Fendrich, Michael and Julia Yun Soo Kim. 2002. "The Experience and Acceptability of Employer Drug Testing: Poll Trends." The Journal of Drug Issues. Issue 1: 81-96.

Fehrshtman, Chaim, and Uri Gneezy. 2001. "Discrimination in a Segmented Society: An Experimental Approach." Quarterly Journal of Economics 116(1): 351-377.

Finlay, Keith. 2009. "Effect of Employer Access to Criminal History Data on the Labor Market Outcomes of Ex-Offenders and Non-Offenders.” In David H. Autor, Ed. Studies of Labor Market Intermediation. Chicago: University of Chicago Press.

Fryer, Jr., Roland G., Devah Pager, and Jörg Spenkuch. 2011. "Racial Disparities in Job Finding and Offered Wages." NBER Working Paper \#17462. 
Gilens, Martin. 1996. “'Race Coding’ and White Opposition to Welfare.” American Political Science Review. 90(3): 593-604.

Government Accountability Office. "Drug Testing: Undercover Tests Reveal Significant Vulnerabilities in DOT's Drug Testing Program." Testimony before the Subcommittees on Highways and Transit, Committee on Transportation and Infrastructure, House of Representatives. GAO08-225T (Nov. 2007).

Hartwell, Tyler D.; Steele, Paul D.; French, Michael T.; and Rodman, Nathaniel F. "The Prevalence of Drug Testing in the Workplace.” Monthly Labor Review. (November, 1996): 35-61.

Heckman, James J. and Bo Honore. 1990. "The Empirical Content of the Roy Model." Econometrica. 58(5): 1121-1149.

Heckman, James J, and Guilherme Sedlacek. 1985. "Heterogeneity, Aggregation, and Market Wage Functions: An Empirical Model of Self-Selection in the Labor Market." The Journal of Political Economy. 93(6): 1077-1125.

Holzer, Harry J., Steven Raphael, and Michael A. Stoll. 2006. "Perceived Criminality, Criminal Background Checks, and the Racial Hiring Practices of Employers." Journal of Law and Economics. 49(2): 451-480.

Jacobson, M. 2003. "Drug Testing in the Trucking Industry: The Effect on Highway Safety." Journal of Law and Economics. 46(1): 131-156.

Kaestner, Robert. 1999. "Does Drug Use Cause Poverty?” In The Economic Analysis of Substance Use and Abuse: An Integration of Econometrics and Behavioral Economics Research. Frank J. Chaloupka, Michael Grossman, Warren K. Bickel, and Henry Saffer, eds. Chicago: University of Chicago Press.

Katz, Lawrence F. and Kevin M. Murphy. 1992. "Changes in Relative Wages, 1963-1987: Supply and Demand Factors." The Quarterly Journal of Economics. 107(1): 35-78.

King, Miriam; Steven Ruggles, J. Trent Alexander, Sarah Flood, Katie Genadek, Matthew B. Schroeder, Brandon Trampe, and Rebecca Vick. Integrated Public Use Microdata Series, Current Population Survey: Version 3.0. [Machine-readable database]. Minneapolis, MN: University of Minnesota 2010.

Knudsen, Hannah K.; Paul M. Roman; and J. Aaron Johnson. 2003. "Organizational Compatibility and Workplace Drug Testing: Modeling the Adoption of Innovative Social Control Practices." Sociological Forum. 18(4): 621-640.

Lu, Natalie T.; Bruce G. Taylor; K. Jack Riley. 2001. "The Validity of Adult Arrestee Self-reports of Crack Cocaine Use." American Journal of Drug and Alcohol Abuse. 27(3): 399-419.

Lundberg, Shelly J. and Richard Startz. 1983. "Private Discrimination and Social Intervention in Competitive Labor Markets." The American Economic Review. 73(3):340-347.

Lange, R., Cabanilla, B., Moler, G., Frankenfield, D., and Fudala, P. 1994. "Preemployment Drug Screening at The Johns Hopkins Hospital, 1989 and 1991." American Journal of Drug and Alcohol Abuse._ 20(1): 35-47.

Mas, A. and Morantz, A. 2008. "Does Post-Accident Drug Testing Reduce Injuries? Evidence from a Large Retail Chain." American Law and Economics Review. 10(2): 246-302.

Mehay, Stephen and Pacula, Rosalie Liccardo. "The Effectiveness of Workplace Drug Prevention Policies: Does Zero-Tolerance Work?” NBER Working Paper \#7383 (Oct. 1999).

Mensch, Barbara S. and Denise B. Kandel. 1988. "Underreporting of Substance Use in a National Longitudinal Youth Cohort: Individual and Interviewer Effects.” Public Opinion Quarterly. Vol 52: 100-124.

National Research Council, Institute of Medicine. Under the Influence? Drugs and the American Workplace. Washington, D.C.:National Academy Press (1994).

Oettinger, Gerald S. 1996. "Statistical Discrimination and the Early Career Evolution of the Black- 
White Wage Gap." Journal of Labor Economics. 14(1): 52-78.

Provine, Doris Marie. 2007. Unequal under Law: Race in the War on Drugs. Chicago: University of Chicago Press.

Quest Diagnostics. "Use of Methamphetamine among US Workers and Job Applicants Drops 22 Percent in 2007 and Cocaine Use Slows Dramatically, Reports Quest Diagnostics: Findings from Quest Diagnostics Drug Testing Index also show that overall drug positivity remains at record lows." http://www.questdiagnostics.com/employersolutions/dti/2008 03/dti.pdf. Madison, New Jersey: Press release (12 March, 2008).

Stoll, Michael A. and Shawn Bushway. 2008. "Effect of Criminal Background Checks on Hiring ExOffenders." Criminology and Public Policy. 7(3): 371-404.

Tunnell, Kenneth D. Pissing on Demand: Workplace Drug Testing and the Rise of the Detox Industry. New York: New York University Press, 2004.

Western, Bruce. 2006. Punishment and Inequality in America. New York: Russell Sage.

Wozniak, Abigail. 2011. "Field Perspectives on the Causes of Low Employment among Less Skilled Black Men." American Journal of Economics and Sociology. 70(3): 811-844.

U.S. Department of Labor. "Survey of Employer Anti-Drug Programs." Report \#760. U.S. Department of Labor, Bureau of Labor Statistics: January (1989).

U.S. Department of Justice. "A Comparison of Urinalysis Technologies for Drug Testing in Criminal Justice." National Institute of Justice Research Report. (Nov. 1991). 
Table 1: Share of Establishments with a Drug Testing Program

\begin{tabular}{lccc}
\hline & $\mathbf{1 9 8 8}$ & $\mathbf{1 9 9 3}$ & $\mathbf{1 9 9 7 - 2 0 0 6}$ \\
\hline Total & 3.2 & 48.4 & 46.3 \\
By Establishment Size & & & \\
$1-9$ & 0.8 & - & 21.3 \\
$10-49$ & 6.4 & - & $38.4^{\mathrm{a}}$ \\
$50-99$ & 12.4 & 40.2 & $49.3^{\mathrm{b}}$ \\
$100-249$ & 17.2 & 61.4 & 66.3 \\
$250-499$ & 29.7 & & \\
$500-999$ & 30.6 & 70.9 & 74.8 \\
$1000-4999$ & 41.8 & &
\end{tabular}

\section{By Industry}

Mining 21.6

Construction $\quad 2.3$

$\begin{array}{lll}21.6 & 69.6 & 86.0\end{array}$

Durable Mfg. 9.9

Non-durable Mfg. $\quad 9.1$

Transportation $\quad 14.9$

Communic.,Utilities $\quad 17.6$

Wholesale trade $\quad 5.3$

Retail trade $\quad 0.7$

FIRE $\quad 3.2$

Services $\quad 1.4$

Agriculture

Government

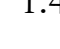

$60.2 \quad 68.6$

\section{By Region}

Northeast

$\begin{array}{ll}1.9 & 33.3\end{array}$

Midwest

3.8

South

3.9

50.3

2.8

72.4

72.4

$53.7-60.1$

60.1
42.5

$\begin{array}{ll}22.6 & 39.7\end{array}$

$\begin{array}{ll}27.9 & 36.3\end{array}$

- 22.3

- 61.2

West

56.3

Notes: Data for 1989 are from U.S. Department of Labor (1989), Tables 1 and 2. Data for 1993 are from Hartwell et. al. (1996) Table 1. Numbers in both columns refer to the share of establishments with any kind of drug testing. Note that because the 1993 sample excludes establishments with fewer than 50 employees, some of the increase in total and industry level testing shares is due to dropping a part of the sample where testing is less prevalent. Data for 1997-2006 are average shares of 22-49 year old employees in the NSDUH reporting that their employer conducts some form of drug testing.

a This number is for establishments with 10-24 employees.

b This number is for establishments with 25-99 employees. 
Table 2: Changes in Reported Employer Drug Testing in the NSDUH, 2002-03 to 2007-09

\begin{tabular}{|c|c|c|c|c|c|c|}
\hline & \multicolumn{3}{|c|}{ Levels } & \multicolumn{3}{|c|}{ Percentage Point Changes } \\
\hline & $\begin{array}{c}\text { Any form } \\
\text { of drug } \\
\text { testing }\end{array}$ & $\begin{array}{c}\text { Drug } \\
\text { testing at } \\
\text { hiring } \\
\end{array}$ & $\begin{array}{c}\text { Random } \\
\text { drug } \\
\text { testing }\end{array}$ & $\begin{array}{c}\text { Any form } \\
\text { of drug } \\
\text { testing }\end{array}$ & $\begin{array}{c}\text { Drug } \\
\text { testing at } \\
\text { hiring } \\
\end{array}$ & $\begin{array}{c}\text { Random } \\
\text { drug } \\
\text { testing }\end{array}$ \\
\hline \multicolumn{7}{|l|}{$2002-03$} \\
\hline Pro-testing & 50.8 & 43.9 & 32.5 & - & - & - \\
\hline Anti-testing & 32.5 & 26.8 & 19.3 & - & - & - \\
\hline Unclassified & 42.4 & 36.8 & 24.4 & - & - & - \\
\hline \multicolumn{7}{|l|}{ 2007-09 } \\
\hline Pro-testing & 54.8 & 48.3 & 35.8 & 4.1 & 4.4 & 3.3 \\
\hline Anti-testing & 35.8 & 29.6 & 21.0 & 3.3 & 2.8 & 1.6 \\
\hline Unclassified & 47.6 & 41.9 & 29.1 & 5.2 & 5.1 & 4.7 \\
\hline
\end{tabular}

Notes: Cells are cross-state averages of employed respondents answering affirmatively to a question on whether their employer conducts the listed form of testing in the 2002 - 2003 and 2007 - 2009 waves of the NSDUH. All averages weighted by 1000's of US population represented by respondents to "Any drug testing" question in 2002-03. Pro-, antiand unclassified states are defined in Appendix Table A1. 
Table 3: Descriptive Statistics for the March CPS Sample, 1980-2010

\begin{tabular}{|c|c|c|c|c|}
\hline & $\begin{array}{c}\text { Overall } \\
\text { Mean }\end{array}$ & $\begin{array}{l}\text { All States, } \\
1980-1988\end{array}$ & $\begin{array}{c}\text { Pro-Testing } \\
\text { States, } \\
1980-1988 \\
\end{array}$ & $\begin{array}{c}\text { Anti-Testing } \\
\text { States, 1980- } \\
1988 \\
\end{array}$ \\
\hline Age & 35.7 & 34.2 & 34.2 & 34.1 \\
\hline Employed & 0.75 & 0.72 & 0.72 & 0.75 \\
\hline High testing industry & 0.28 & 0.33 & 0.32 & 0.32 \\
\hline Employed in large firm $(>500)$ & 0.44 & 0.42 & 0.43 & 0.36 \\
\hline Real hourly wage $(\$ 2000)$ & 14.8 & 12.6 & 12.08 & 11.75 \\
\hline Log real hourly wage & 2.45 & 2.36 & 2.31 & 2.31 \\
\hline In wage sample & 0.73 & 0.72 & 0.71 & 0.74 \\
\hline Covered by group health & 0.53 & 0.59 & 0.58 & 0.57 \\
\hline Covered by pension & 0.52 & 0.50 & 0.48 & 0.48 \\
\hline Female & 0.52 & 0.52 & 0.52 & 0.51 \\
\hline Black & 0.10 & 0.09 & 0.13 & 0.03 \\
\hline Hispanic & 0.13 & 0.10 & 0.06 & 0.02 \\
\hline Any postsecondary & 0.49 & 0.39 & 0.36 & 0.39 \\
\hline Young (ages 18-25) & 0.21 & 0.26 & 0.26 & 0.25 \\
\hline Pro-testing dummy & 0.10 & 0.01 & 0.02 & 0.00 \\
\hline Anti-testing dummy & 0.04 & 0.00 & 0.00 & 0.00 \\
\hline \multicolumn{5}{|l|}{ Black Subsample } \\
\hline Employed & 0.67 & 0.63 & 0.62 & 0.67 \\
\hline High testing industry & 0.31 & 0.37 & 0.36 & 0.41 \\
\hline Employed in large firm $(>500)$ & 0.56 & 0.55 & 0.52 & 0.57 \\
\hline Covered by group health & 0.54 & 0.59 & 0.55 & 0.63 \\
\hline Covered by pension & 0.54 & 0.52 & 0.45 & 0.55 \\
\hline Log real hourly wage & 2.32 & 2.23 & 2.09 & 2.27 \\
\hline \multicolumn{5}{|l|}{ White Subsample } \\
\hline Employed & 0.77 & 0.75 & 0.73 & 0.75 \\
\hline High testing industry & 0.27 & 0.32 & 0.32 & 0.32 \\
\hline Employed in large firm $(>500)$ & 0.43 & 0.42 & 0.43 & 0.36 \\
\hline Covered by group health & 0.55 & 0.59 & 0.58 & 0.57 \\
\hline Covered by pension & 0.55 & 0.50 & 0.48 & 0.48 \\
\hline Log real hourly wage & 2.50 & 2.39 & 2.35 & 2.31 \\
\hline
\end{tabular}

Notes: Data are from the IPUMS version of the annual March CPS surveys. Sample is restricted to those ages 18-55. Estimates are unweighted. "High testing industry" is defined conditional on employment and is equal to one if an individual is employed in mining, transportation, communications and utilities, government or wholesale trade. One state, South Carolina, first adopted pro-drug testing legislation in 1985. 
Table 4: Non-user - user difference in high testing industry employment rates (adjusted) by time period and Census division testing intensity

\section{i. Whole Sample}

\begin{tabular}{lccc}
\hline Time Period & $\begin{array}{c}\text { Pre-Testing } \\
\mathbf{1 9 8 5 - 1 9 8 8}\end{array}$ & $\begin{array}{c}\text { Transition } \\
\mathbf{1 9 8 9 - 1 9 9 3}\end{array}$ & $\begin{array}{c}\text { Post-Testing } \\
\mathbf{1 9 9 4 - 1 9 9 7}\end{array}$ \\
\hline Lowest & 0.021 & 0.061 & 0.018 \\
& $(0.026)$ & $(0.012)$ & $(0.017)$ \\
Intermediate & 0.017 & 0.041 & 0.075 \\
& $(0.031)$ & $(0.010)$ & $(0.016)$ \\
Highest & 0.038 & 0.047 & 0.043 \\
& $(0.026)$ & $(0.014)$ & $(0.020)$ \\
\hline
\end{tabular}

ii. Blacks only

\begin{tabular}{lccc}
\hline Time Period & $\begin{array}{c}\text { Pre-Testing } \\
\mathbf{1 9 8 5 - 1 9 8 8}\end{array}$ & $\begin{array}{c}\text { Transition } \\
\mathbf{1 9 8 9 - 1 9 9 3}\end{array}$ & $\begin{array}{c}\text { Post-Testing } \\
\mathbf{1 9 9 4 - 1 9 9 7}\end{array}$ \\
\hline Lowest & 0.007 & 0.031 & -0.020 \\
Intermediate & $(0.061)$ & $(0.029)$ & $(0.041)$ \\
& 0.078 & 0.023 & 0.101 \\
Highest & $(0.062)$ & $(0.024)$ & $(0.041)$ \\
& 0.039 & 0.032 & 0.075 \\
& $(0.059)$ & $(0.030)$ & $(0.039)$ \\
\hline
\end{tabular}

iii. Whites only

\begin{tabular}{lccc}
\hline Time Period & $\begin{array}{c}\text { Pre-Testing } \\
\mathbf{1 9 8 5 - 1 9 8 8}\end{array}$ & $\begin{array}{c}\text { Transition } \\
\mathbf{1 9 8 9 - 1 9 9 3}\end{array}$ & $\begin{array}{c}\text { Post-Testing } \\
\mathbf{1 9 9 4 - 1 9 9 7}\end{array}$ \\
\hline Lowest & 0.018 & 0.070 & 0.007 \\
& $(0.033)$ & $(0.015)$ & $(0.022)$ \\
Intermediate & -0.008 & 0.051 & 0.068 \\
& $(0.040)$ & $(0.013)$ & $(0.019)$ \\
Highest & 0.047 & 0.047 & 0.030 \\
& $(0.033)$ & $(0.019)$ & $(0.026)$ \\
\hline
\end{tabular}

Notes: Data from National Survey on Drug Use and Health, 1985-1997. Census division testing intensity tabulated from Appendix Table A4. Cells show difference between mean adjusted high testing industry employment for (monthly) nonusers and monthly users. Standard errors of the difference in parentheses. High testing industry employment is regression adjusted using controls for demographics (age, race, Hispanic ethnicity, sex, and educational attainment), demographic-specific cubic time trends and group-specific region fixed effects, and all relevant main effects. Lowest testing divisions are New England, the mid-Atlantic, and Pacific. Intermediate testing regions are the West North Central, South Atlantic, and Mountain. Highest testing regions are the East and West South Central and East North Central. 
Table 5: Impacts of Pro-Testing Legislation by Demographic Group

\begin{tabular}{|c|c|c|c|c|c|}
\hline $\begin{array}{l}\text { Dependent } \\
\text { Variable: }\end{array}$ & Employed & $\begin{array}{c}\text { Employed in } \\
\text { High Test } \\
\text { Ind. }\end{array}$ & $\begin{array}{l}\text { Employed in } \\
\text { Large Firm }\end{array}$ & $\begin{array}{c}\text { Covered by } \\
\text { Health or } \\
\text { Pension } \\
\end{array}$ & $\begin{array}{c}\text { Log Real } \\
\text { Hourly Wage }\end{array}$ \\
\hline \multirow[t]{2}{*}{ Black x Pro } & 0.001 & 0.016 & 0.021 & 0.03 & 0.014 \\
\hline & $(0.006)$ & $(0.01)$ & $(0.01)^{*}$ & $(0.008)^{* * *}$ & $(0.009)$ \\
\hline \multirow[t]{2}{*}{ Hispanic x Pro } & -0.006 & -0.008 & -0.003 & -0.001 & -0.019 \\
\hline & $(0.008)$ & $(0.01)$ & $(0.023)$ & $(0.028)$ & $(0.013)$ \\
\hline \multirow[t]{2}{*}{ Female x Pro } & 0.001 & -0.016 & -0.014 & -0.012 & -0.009 \\
\hline & $(0.008)$ & $(0.008)$ & $(0.005)^{* *}$ & $(0.007)$ & $(0.009)$ \\
\hline \multirow[t]{2}{*}{ Age $18-25$ x Pro } & 0.002 & -0.01 & -0.002 & 0.009 & -0.004 \\
\hline & $(0.005)$ & $(0.007)$ & $(0.006)$ & $(0.006)$ & $(0.007)$ \\
\hline \multirow[t]{2}{*}{ Low Skill x Pro } & 0.001 & 0.008 & 0.01 & 0.013 & 0.013 \\
\hline & $(0.005)$ & $(0.006)$ & $(0.006)$ & $(0.005)^{*}$ & $(0.005)^{*}$ \\
\hline \multirow[t]{2}{*}{ Pro-Testing Law } & 0.01 & -0.008 & 0.009 & 0.004 & 0.042 \\
\hline & $(0.01)$ & $(0.009)$ & $(0.008)$ & $(0.011)$ & $(0.011)^{* * *}$ \\
\hline \multirow[t]{2}{*}{ Black } & -0.154 & 0.046 & 0.116 & 0.005 & -0.107 \\
\hline & $(0.005)^{* * *}$ & $(0.009)^{* * *}$ & $(0.052)^{*}$ & $(0.007)$ & $(0.008) * * *$ \\
\hline \multirow[t]{2}{*}{ Hispanic } & -0.06 & 0.119 & -0.174 & 0.015 & -0.076 \\
\hline & $(0.006)^{* * *}$ & $(0.005)^{* * *}$ & $(0.04)^{* * *}$ & $(0.011)$ & $(0.016)^{* * *}$ \\
\hline \multirow[t]{2}{*}{ Female } & -0.225 & -0.184 & -0.016 & -0.143 & -0.393 \\
\hline & $(0.006)^{* * *}$ & $(0.005)^{* * *}$ & $(0.018)$ & $(0.004)^{* * *}$ & $(0.005)^{* * *}$ \\
\hline \multirow[t]{2}{*}{ Low Skill } & -0.089 & 0.138 & -0.107 & -0.057 & -0.185 \\
\hline & $(0.003) * * *$ & $(0.005)^{* * *}$ & $(0.027)^{* * *}$ & $(0.003)^{* * *}$ & $(0.005)^{* * *}$ \\
\hline \multirow[t]{2}{*}{ Age } & 0.04 & 0.021 & -0.004 & 0.039 & 0.069 \\
\hline & $(0.001)^{* * *}$ & $(0.001)^{* * *}$ & $(0.001)^{* * *}$ & $(0.001)^{* * *}$ & $(0.001)^{* * *}$ \\
\hline \multirow[t]{2}{*}{$\mathrm{Age}^{\wedge} 2$} & -0.001 & 0.00 & 0.00 & 0.00 & -0.001 \\
\hline & $(0.00)^{* * *}$ & $(0.00)^{* * *}$ & $(0.00) * * *$ & $(0.00) * * *$ & $(0.00)^{* * *}$ \\
\hline $\mathrm{N}$ & 2789031 & 2096833 & 1753213 & 2312334 & 2043901 \\
\hline $\begin{array}{c}\text { Effect Sire: } \\
\text { Black - Female }\end{array}$ & 0.00 & 0.032 & 0.035 & 0.015 & 0.023 \\
\hline $\begin{array}{c}\mathrm{H}_{0}: \text { Blacks }=\text { Female } \\
\text { (p-value })\end{array}$ & 0.99 & 0.05 & 0.01 & 0.001 & 0.13 \\
\hline
\end{tabular}

Notes: Data are from March CPS 1980-2010, IPUMS version. Sample is individuals ages 18-55. Firm size only available from 1988 onwards. Wage equation is further restricted to those with positive earnings within the $3^{\text {rd }}$ and $97^{\text {th }}$ percentiles of the real wage distribution in the overall sample. Specifications are estimated via OLS. All include a cubic time trend, interactions of the cubic time trend components with all demographic variables, a full set of state $\mathrm{x}$ demographic group dummy variables, and a full set of state $\mathrm{x}$ cubic time trends. Standard errors clustered on state in parentheses. ${ }^{* * *}$ indicates significance at the $.1 \%$ level, ** at $1 \%$, and * at $5 \%$. 
Table 6: Impacts of Pro- and Anti-Testing Legislation by Demographic Group

\begin{tabular}{|c|c|c|c|c|c|}
\hline $\begin{array}{l}\text { Dependent } \\
\text { Variable: }\end{array}$ & Employed & $\begin{array}{l}\text { Employed in } \\
\text { High Test } \\
\text { Ind. }\end{array}$ & $\begin{array}{l}\text { Employed in } \\
\text { Large Firm }\end{array}$ & $\begin{array}{c}\text { Covered by } \\
\text { Health or } \\
\text { Pension }\end{array}$ & $\begin{array}{c}\text { Log Real } \\
\text { Hourly Wage }\end{array}$ \\
\hline \multirow[t]{2}{*}{ Black x Pro } & 0.001 & 0.015 & 0.02 & 0.029 & 0.012 \\
\hline & $(0.006)$ & $(0.01)$ & $(0.01)^{*}$ & $(0.008)^{* * *}$ & $(0.009)$ \\
\hline \multirow[t]{2}{*}{ Hispanic x Pro } & -0.006 & -0.009 & -0.004 & -0.002 & -0.02 \\
\hline & $(0.008)$ & $(0.01)$ & $(0.023)$ & $(0.028)$ & $(0.013)$ \\
\hline \multirow[t]{2}{*}{ Female x Pro } & 0.001 & -0.015 & -0.014 & -0.012 & -0.009 \\
\hline & $(0.008)$ & $(0.008)$ & $(0.005)^{* * *}$ & $(0.007)$ & $(0.009)$ \\
\hline \multirow[t]{2}{*}{ Young x Pro } & 0.003 & -0.011 & -0.002 & 0.008 & -0.004 \\
\hline & $(0.005)$ & $(0.007)$ & $(0.006)$ & $(0.006)$ & $(0.007)$ \\
\hline \multirow[t]{2}{*}{ Low Skill x Pro } & 0.00 & 0.009 & 0.01 & 0.014 & 0.014 \\
\hline & $(0.005)$ & $(0.006)$ & $(0.006)$ & $(0.005)^{*}$ & $(0.006)^{*}$ \\
\hline \multirow[t]{2}{*}{ Black x Anti } & 0.003 & -0.048 & -0.012 & -0.022 & -0.037 \\
\hline & $(0.017)$ & $(0.023)^{*}$ & $(0.009)$ & $(0.021)$ & $(0.024)$ \\
\hline \multirow[t]{2}{*}{ Hispanic x Anti } & 0.002 & -0.036 & -0.017 & -0.057 & -0.044 \\
\hline & (0.014) & (0.031) & (0.014) & $(0.028)$ & $(0.047)$ \\
\hline \multirow[t]{2}{*}{ Female x Anti } & 0.004 & 0.007 & 0.012 & 0.008 & 0.012 \\
\hline & $(0.01)$ & $(0.009)$ & $(0.007)$ & $(0.008)$ & $(0.005)^{*}$ \\
\hline \multirow[t]{2}{*}{ Young x Anti } & 0.01 & -0.011 & 0.002 & -0.018 & -0.004 \\
\hline & $(0.011)$ & $(0.006)$ & $(0.017)$ & $(0.007)^{*}$ & $(0.011)$ \\
\hline \multirow[t]{2}{*}{ Low Skill x Anti } & -0.014 & 0.015 & 0.005 & 0.018 & 0.002 \\
\hline & $(0.008)$ & $(0.013)$ & $(0.007)$ & $(0.006)^{* *}$ & $(0.01)$ \\
\hline \multirow[t]{2}{*}{ Pro-Testing Law } & 0.01 & -0.008 & 0.009 & 0.004 & 0.042 \\
\hline & $(0.01)$ & $(0.009)$ & $(0.008)$ & (0.011) & $(0.011)^{* * *}$ \\
\hline \multirow[t]{2}{*}{ Anti-Testing Law } & 0.02 & 0.00 & 0.001 & -0.014 & -0.007 \\
\hline & $(0.007)^{* *}$ & $(0.005)$ & $(0.014)$ & $(0.011)$ & $(0.033)$ \\
\hline $\mathrm{N}$ & 2789031 & 2096833 & 1753213 & 2312334 & 2043901 \\
\hline $\begin{array}{l}\text { Effect Size: Black x Pro } \\
\text { - Black x Anti }\end{array}$ & -0.002 & 0.063 & 0.032 & 0.051 & 0.049 \\
\hline $\begin{array}{l}\mathrm{H}_{0}: \text { Black x Pro }= \\
\text { Black x Anti (p-val) }\end{array}$ & 0.89 & 0.01 & 0.01 & 0.03 & 0.05 \\
\hline $\begin{array}{l}\text { Effect Size: Female x } \\
\text { Pro - Female x Anti }\end{array}$ & -0.003 & -0.022 & -0.026 & -0.02 & -0.021 \\
\hline $\begin{array}{l}\mathrm{H}_{0}: \text { Female x Pro }= \\
\text { Female x Anti }(\mathrm{p}-\mathrm{val})\end{array}$ & 0.79 & 0.05 & 0.004 & 0.04 & 0.04 \\
\hline
\end{tabular}

Notes: Data are from March CPS 1980-2010, IPUMS version. Sample is individuals ages 18-55. Firm size only available from 1988 onwards. Wage equation is further restricted to those with positive earnings within the $3^{\text {rd }}$ and $97^{\text {th }}$ percentiles of the real wage distribution in the overall sample. Specifications are estimated via OLS. All include include all additional controls listed in Table 5, all relevant main effects, a cubic time trend, interactions of the cubic time trend components with all demographic variables, a full set of state $\mathrm{x}$ demographic group dummy variables, and a full set of state $\mathrm{x}$ cubic time trends. Standard errors clustered on state in parentheses. $* * *$ indicates significance at the .1\% level, ** at $1 \%$, and $*$ at $5 \%$. 
Table 7: Impacts by Exclusive Demographic Groups

\begin{tabular}{|c|c|c|c|c|c|}
\hline $\begin{array}{l}\text { Dependent } \\
\text { Variable: }\end{array}$ & Employed & $\begin{array}{c}\text { Employed in } \\
\text { High Test } \\
\text { Ind. }\end{array}$ & $\begin{array}{l}\text { Employed in } \\
\text { Large Firm }\end{array}$ & $\begin{array}{c}\text { Covered by } \\
\text { Health or } \\
\text { Pension }\end{array}$ & $\begin{array}{c}\text { Log Real } \\
\text { Hourly Wage }\end{array}$ \\
\hline \multicolumn{6}{|c|}{ Pro-Testing $\mathbf{x} \ldots$ (HS White Men are omitted) } \\
\hline \multirow[t]{2}{*}{ LS Black Men } & -0.005 & 0.038 & 0.045 & 0.042 & 0.034 \\
\hline & $(0.014)$ & $(0.02)$ & $(0.012)^{* * *}$ & $(0.011)^{* * *}$ & $(0.016)^{*}$ \\
\hline \multirow[t]{2}{*}{ HS Black Men } & -0.004 & -0.007 & 0.017 & 0.025 & 0.006 \\
\hline & $(0.011)$ & $(0.022)$ & $(0.016)$ & $(0.013)$ & $(0.016)$ \\
\hline \multirow[t]{2}{*}{ LS Black Women } & 0.016 & 0.011 & 0.008 & 0.044 & 0.014 \\
\hline & $(0.015)$ & $(0.02)$ & $(0.013)$ & $(0.01)^{* * *}$ & $(0.013)$ \\
\hline \multirow[t]{2}{*}{ HS Black Women } & -0.018 & 0.006 & -0.007 & -0.001 & -0.008 \\
\hline & $(0.012)$ & $(0.015)$ & $(0.011)$ & $(0.011)$ & $(0.014)$ \\
\hline \multirow[t]{2}{*}{ LS White Men } & 0.002 & 0.016 & 0.008 & 0.014 & 0.015 \\
\hline & $(0.007)$ & $(0.009)$ & $(0.005)$ & $(0.006)^{*}$ & $(0.007)^{*}$ \\
\hline \multirow[t]{2}{*}{ LS White Women } & -0.01 & -0.008 & -0.003 & -0.004 & 0.00 \\
\hline & $(0.011)$ & $(0.01)$ & $(0.008)$ & $(0.011)$ & $(0.008)$ \\
\hline \multirow[t]{2}{*}{ HS White Women } & -0.001 & -0.009 & -0.012 & -0.006 & -0.005 \\
\hline & $(0.007)$ & $(0.008)$ & $(0.006)^{*}$ & $(0.006)$ & $(0.007)$ \\
\hline \multicolumn{6}{|c|}{ Anti-Testing $\mathbf{x} \ldots$ (HS White Men are omitted) } \\
\hline \multirow[t]{2}{*}{ LS Black Men } & -0.023 & -0.071 & -0.076 & -0.046 & -0.091 \\
\hline & $(0.038)$ & $(0.04)$ & $(0.045)$ & $(0.046)$ & $(0.063)$ \\
\hline \multirow[t]{2}{*}{ HS Black Men } & -0.022 & 0.009 & 0.026 & 0.046 & -0.013 \\
\hline & $(0.016)$ & $(0.051)$ & $(0.058)$ & $(0.036)$ & $(0.018)$ \\
\hline \multirow[t]{2}{*}{ LS Black Women } & 0.014 & -0.051 & 0.048 & -0.023 & -0.028 \\
\hline & $(0.021)$ & $(0.041)$ & $(0.017)^{* * *}$ & $(0.037)$ & $(0.034)$ \\
\hline \multirow[t]{2}{*}{ HS Black Women } & 0.024 & -0.032 & -0.018 & -0.012 & -0.013 \\
\hline & $(0.016)$ & $(0.049)$ & $(0.046)$ & $(0.021)$ & $(0.015)$ \\
\hline \multirow[t]{2}{*}{ LS White Men } & 0.003 & 0.012 & 0.007 & 0.017 & -0.008 \\
\hline & $(0.006)$ & $(0.01)$ & $(0.016)$ & $(0.013)$ & $(0.018)$ \\
\hline \multirow[t]{2}{*}{ LS White Women } & -0.012 & 0.025 & 0.017 & 0.031 & 0.006 \\
\hline & $(0.006)$ & $(0.015)$ & $(0.012)$ & $(0.014)^{*}$ & $(0.011)$ \\
\hline \multirow[t]{2}{*}{ HS White Women } & 0.009 & -0.001 & 0.008 & 0.007 & -0.006 \\
\hline & $(0.009)$ & $(0.015)$ & $(0.01)$ & $(0.014)$ & $(0.011)$ \\
\hline $\mathrm{N}$ & 2416155 & 1838781 & 1516945 & 2026992 & 1783855 \\
\hline $\begin{array}{l}\text { Effect Size: LSBM x } \\
\text { Pro - LSBM x Anti }\end{array}$ & 0.018 & 0.11 & 0.12 & 0.088 & 0.12 \\
\hline $\begin{array}{l}\mathrm{H}_{0}: \text { LSBM x Pro }= \\
\text { LSBM x Anti (p-value) }\end{array}$ & 0.64 & 0.01 & 0.01 & 0.07 & 0.05 \\
\hline
\end{tabular}

Notes: Data are from March CPS 1980-2006, IPUMS version. Sample is individuals ages 18-55. Hispanics excluded; other races defined as white. HS indicates High Skill (some post-secondary), LS Low Skill (no post-secondary).

Estimation methods are the same as in Table 5. All specifications include controls for age, age ${ }^{2}$, state-year characteristics in Table 5, a cubic time trend plus its interactions with the listed (exclusive) demographic groups, state x demographic group interactions, state-specific cubic time trends, and all relevant main effects. Standard errors clustered on state in parentheses. ${ }^{* * *}$ indicates significance at the $.1 \%$ level, $* *$ at $1 \%$, and $*$ at $5 \%$. 
Table 8: Model with Interactions for Metro Area Drug Testing Exposure

\begin{tabular}{|c|c|c|c|c|c|}
\hline Dependent Variable: & Employed & $\begin{array}{c}\text { Employed } \\
\text { in High } \\
\text { Test Ind. }\end{array}$ & $\begin{array}{c}\text { Employed } \\
\text { in Large } \\
\text { Firm }\end{array}$ & $\begin{array}{c}\text { Covered by } \\
\text { Health or } \\
\text { Pension }\end{array}$ & $\begin{array}{c}\text { Log Real } \\
\text { Hourly } \\
\text { Wage }\end{array}$ \\
\hline \multicolumn{6}{|c|}{ Pro-Testing $\mathbf{x}$... (HS White Men are omitted) } \\
\hline LS Black Men & $\begin{array}{c}0.022 \\
(0.025)\end{array}$ & $\begin{array}{l}-0.014 \\
(0.026)\end{array}$ & $\begin{array}{c}0.008 \\
(0.018)\end{array}$ & $\begin{array}{c}0.06 \\
(0.025)^{*}\end{array}$ & $\begin{array}{c}0.054 \\
(0.032)\end{array}$ \\
\hline HS Black Men & $\begin{array}{c}0.017 \\
(0.012)\end{array}$ & $\begin{array}{l}-0.023 \\
(0.024)\end{array}$ & $\begin{array}{c}0.084 \\
(0.016)^{* * *}\end{array}$ & $\begin{array}{l}-0.016 \\
(0.018)\end{array}$ & $\begin{array}{c}0.024 \\
(0.025)\end{array}$ \\
\hline LS Black Women & $\begin{array}{c}0.006 \\
(0.014)\end{array}$ & $\begin{array}{c}0.043 \\
(0.015)^{* *}\end{array}$ & $\begin{array}{c}-0.079 \\
(0.025)^{* *}\end{array}$ & $\begin{array}{l}-0.045 \\
(0.026)\end{array}$ & $\begin{array}{c}0.037 \\
(0.022)\end{array}$ \\
\hline HS Black Women & $\begin{array}{l}-0.031 \\
(0.019)\end{array}$ & $\begin{array}{c}0.007 \\
(0.019)\end{array}$ & $\begin{array}{c}-0.036 \\
(0.018)^{*}\end{array}$ & $\begin{array}{c}0.031 \\
(0.016)\end{array}$ & $\begin{array}{c}0.053 \\
(0.044)\end{array}$ \\
\hline LS White Men & $\begin{array}{c}0.011 \\
(0.005)^{*}\end{array}$ & $\begin{array}{c}0.025 \\
(0.018)\end{array}$ & $\begin{array}{l}-0.016 \\
(0.012)\end{array}$ & $\begin{array}{l}-0.002 \\
(0.01)\end{array}$ & $\begin{array}{c}0.013 \\
(0.014)\end{array}$ \\
\hline LS White Women & $\begin{array}{l}-0.017 \\
(0.011)\end{array}$ & $\begin{array}{c}0.01 \\
(0.011)\end{array}$ & $\begin{array}{l}-0.007 \\
(0.012)\end{array}$ & $\begin{array}{l}-0.01 \\
(0.021)\end{array}$ & $\begin{array}{l}-0.02 \\
(0.026)\end{array}$ \\
\hline HS White Women & $\begin{array}{c}-0.02 \\
(0.008)^{*}\end{array}$ & $\begin{array}{l}-0.006 \\
(0.018)\end{array}$ & $\begin{array}{l}-0.008 \\
(0.01)\end{array}$ & $\begin{array}{c}-0.014 \\
(0.005)^{* *}\end{array}$ & $\begin{array}{l}-0.014 \\
(0.017)\end{array}$ \\
\hline \multicolumn{6}{|c|}{ Metro Area Drug Testing Exposure x Pro-Testing x ... (HS White Men are omitted) } \\
\hline LS Black Men & $\begin{array}{c}0.013 \\
(0.017)\end{array}$ & $\begin{array}{c}0.056 \\
(0.016) * *\end{array}$ & $\begin{array}{c}0.01 \\
(0.009)\end{array}$ & $\begin{array}{c}0.006 \\
(0.011)\end{array}$ & $\begin{array}{c}-0.01 \\
(0.021)\end{array}$ \\
\hline HS Black Men & $\begin{array}{c}0.015 \\
(0.004)^{* *}\end{array}$ & $\begin{array}{c}0.044 \\
(0.019)^{*}\end{array}$ & $\begin{array}{c}-0.015 \\
(0.004)^{* * *}\end{array}$ & $\begin{array}{c}0.044 \\
(0.014)^{* *}\end{array}$ & $\begin{array}{c}-0.02 \\
(0.022)\end{array}$ \\
\hline LS Black Women & $\begin{array}{c}0.00 \\
(0.007)\end{array}$ & $\begin{array}{c}0.048 \\
(0.01)^{* * *}\end{array}$ & $\begin{array}{c}0.06 \\
(0.014)^{* * *}\end{array}$ & $\begin{array}{c}0.048 \\
(0.025)\end{array}$ & $\begin{array}{c}-0.024 \\
(0.011)^{*}\end{array}$ \\
\hline HS Black Women & $\begin{array}{l}0.001 \\
(0.01)\end{array}$ & $\begin{array}{c}0.046 \\
(0.011)^{* * *}\end{array}$ & $\begin{array}{c}0.038 \\
(0.008)^{* * *}\end{array}$ & $\begin{array}{l}-0.001 \\
(0.007)\end{array}$ & $\begin{array}{l}-0.044 \\
(0.028)\end{array}$ \\
\hline LS White Men & $\begin{array}{c}0.003 \\
(0.004)\end{array}$ & $\begin{array}{c}0.011 \\
(0.012)\end{array}$ & $\begin{array}{c}0.03 \\
(0.006)^{* * *}\end{array}$ & $\begin{array}{c}0.003 \\
(0.007)\end{array}$ & $\begin{array}{l}-0.007 \\
(0.012)\end{array}$ \\
\hline LS White Women & $\begin{array}{c}0.025 \\
(0.01)^{*}\end{array}$ & $\begin{array}{c}0.029 \\
(0.009)^{* *}\end{array}$ & $\begin{array}{c}0.013 \\
(0.007)\end{array}$ & $\begin{array}{l}-0.012 \\
(0.015)\end{array}$ & $\begin{array}{l}-0.025 \\
(0.021)\end{array}$ \\
\hline HS White Women & $\begin{array}{c}0.013 \\
(0.007) \\
\end{array}$ & $\begin{array}{c}0.017 \\
(0.016) \\
\end{array}$ & $\begin{array}{c}0.013 \\
(0.009) \\
\end{array}$ & $\begin{array}{c}-0.013 \\
(0.002)^{* * *} \\
\end{array}$ & $\begin{array}{c}0.004 \\
(0.015) \\
\end{array}$ \\
\hline Observations & 847823 & 651082 & 499655 & 715966 & 639429 \\
\hline
\end{tabular}

Notes: Specifications include "anti' and all anti interactions, but these are not reported. This is 1980-1999 data and limited to 3 years or less after law adoption. Employment in large firm further restricted to 1988-1999. Standard errors clustered on state in parentheses. ${ }^{* * *}$ indicates significance at the $.1 \%$ level, ** at $1 \%$, and $*$ at $5 \%$. 


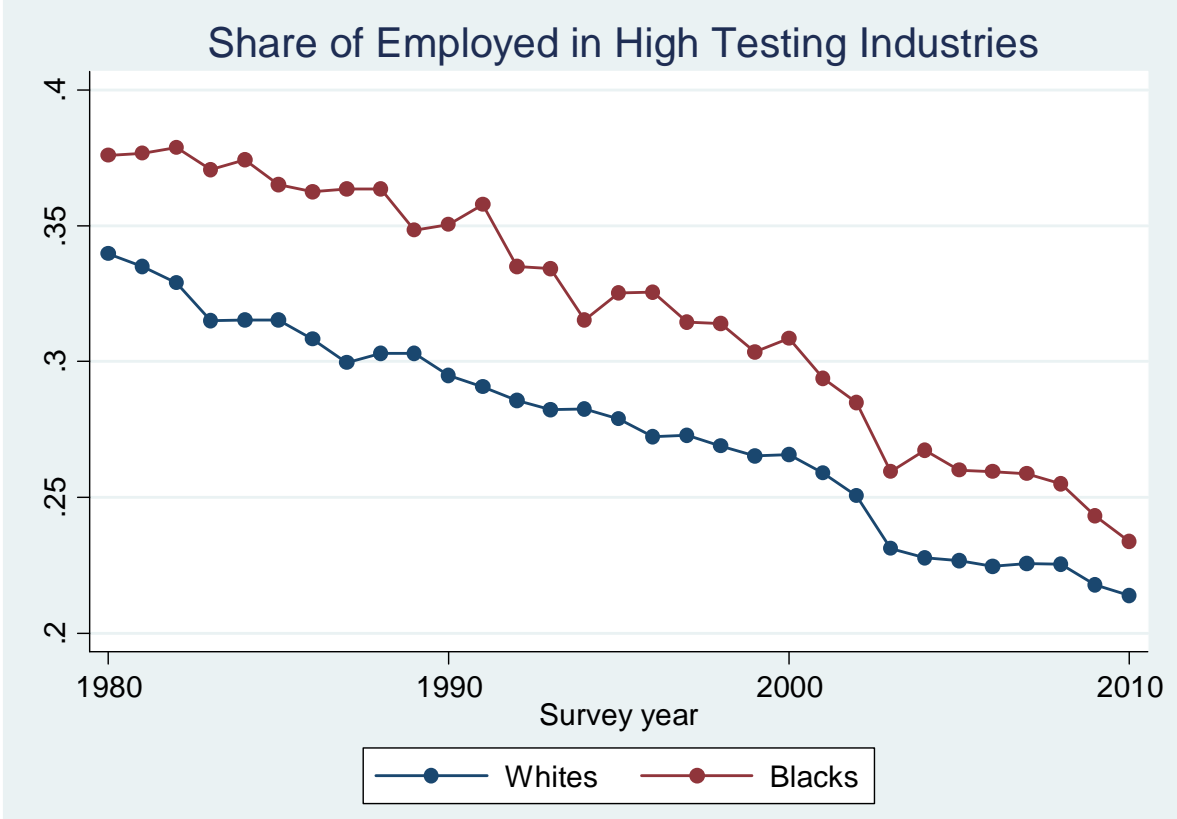

FIGURE 1. Share of employed respondents working in a high testing industry, by race. Data from the CPS ASEC Supplement (March) 1980-2010.

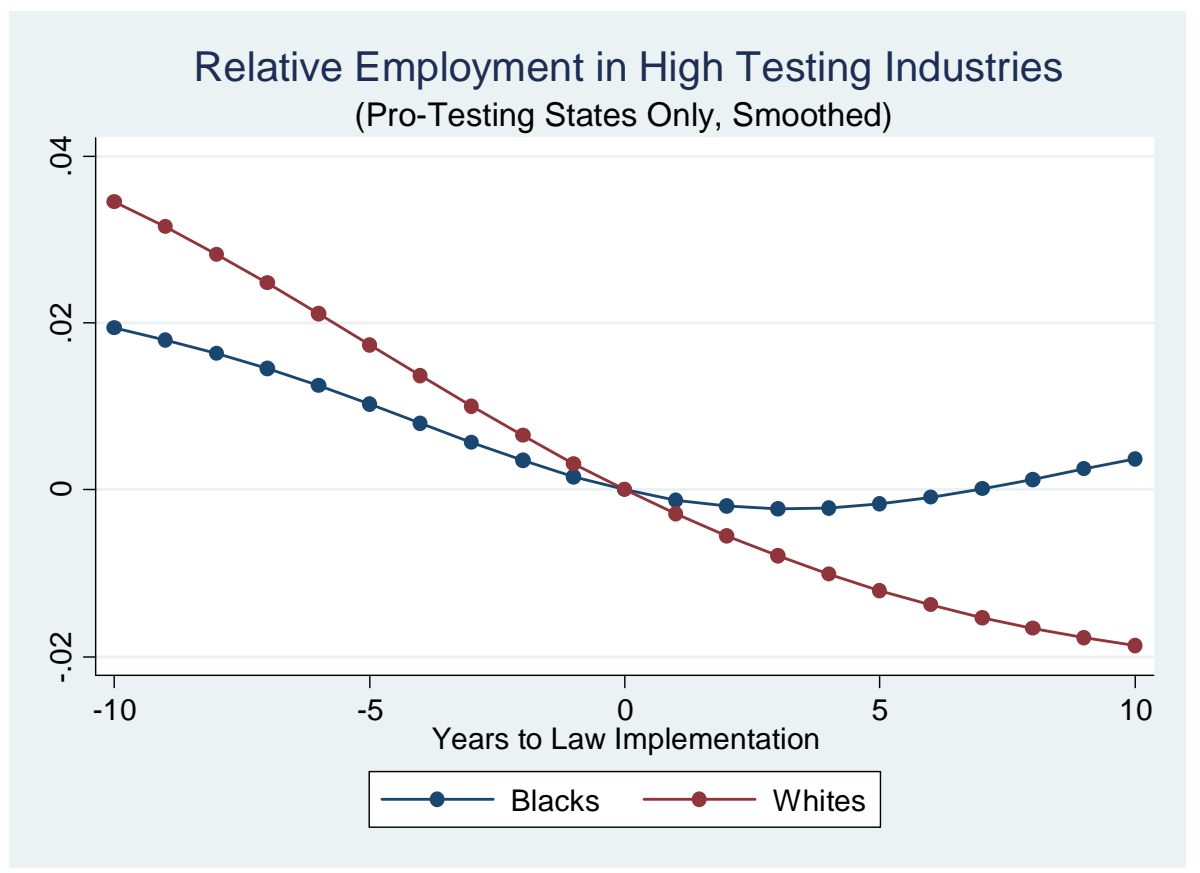

FIGURE 2a. Share of employed respondents working in a high testing industry relative to year in which a pro-testing law was passed, by race. Data from the March CPS 1980-2010. Respondents from states adopting a pro-testing law only. Y-axis is difference between share of employed in high testing industries in $\mathrm{x}$-axis year and in year of passage. 


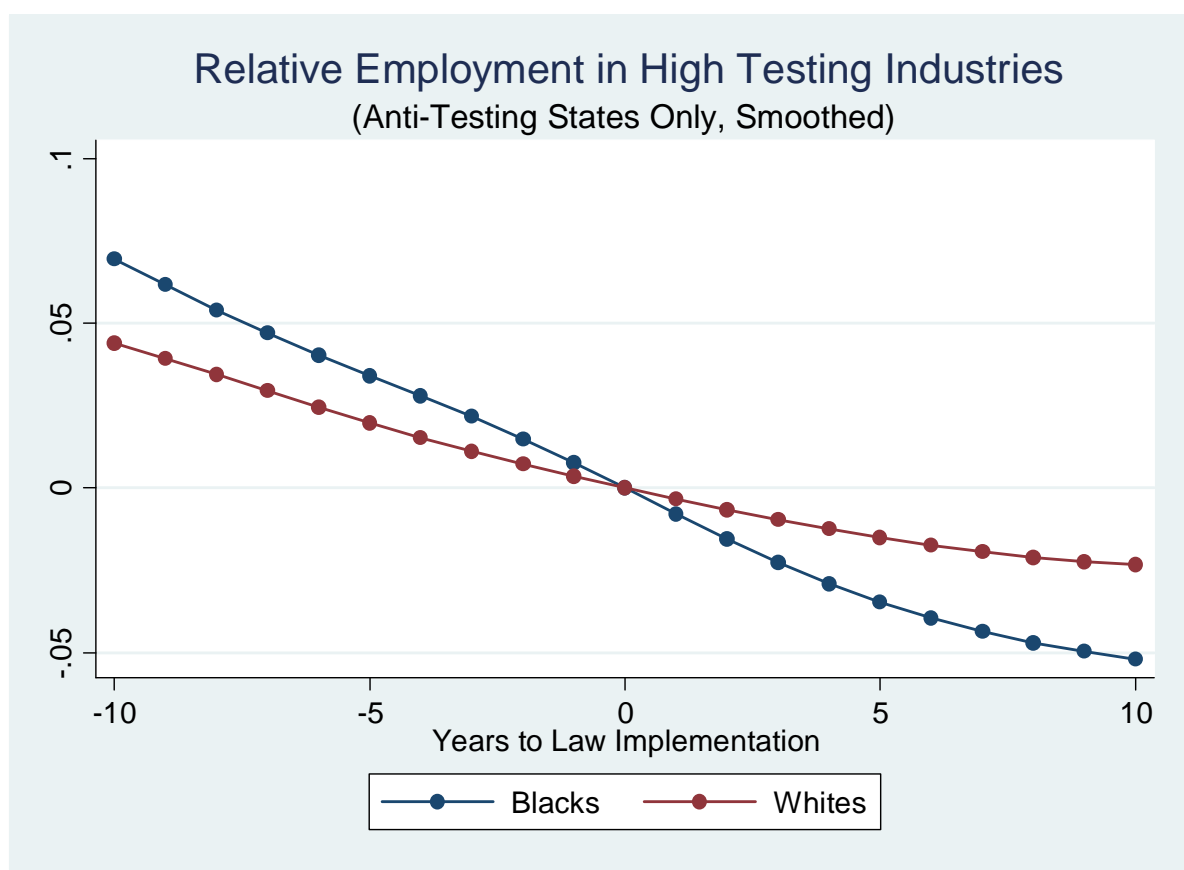

FIGURE 2b. Share of employed respondents working in a high testing industry relative to year in which an anti-testing law was passed, by race. Data from the March CPS 1980-2010. Respondents from states adopting a pro-testing law only. Y-axis is difference between share of employed in high testing industries in $\mathrm{x}$-axis year and in year of passage.

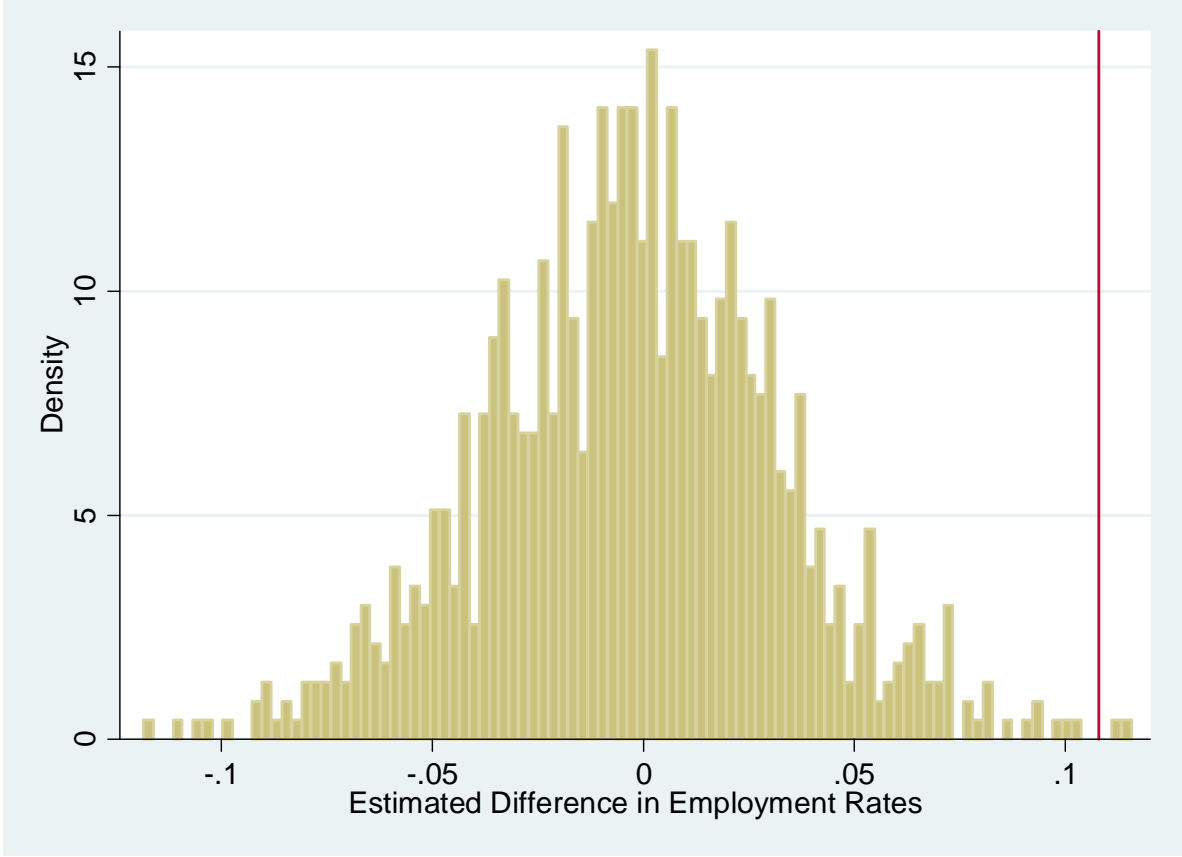

FIGURE 3: Placebo Analysis: Estimated difference in testing sector employment for low skilled black men from regressions using placebo laws. The estimated difference in the figure corresponds to the effect size in column 2 of Table 8 . The figure plots differences estimated from each of 1000 draws of a law change distribution in which states are randomly assigned to "pass" laws that match the actual law change distribution in terms of years of passage, numbers of states passing in a given year, and pro-/anti-testing character of the legislation. 
APPENDICES - NOT FOR PUBLICATION 
APPENDIX Table A1: Employer Drug Testing Regulations and Prevalence by State

\begin{tabular}{|c|c|c|c|c|c|c|}
\hline & \multicolumn{3}{|c|}{$\begin{array}{c}\text { Summary of state drug testing } \\
\text { regulations }\end{array}$} & \multicolumn{3}{|c|}{$\begin{array}{l}\text { Share NSDUH respondents reporting } \\
\text { testing by their employer in } 2002-03\end{array}$} \\
\hline $\begin{array}{c}\text { DeBernardo \& } \\
\text { Nieman } \\
\text { Classification } \\
(2007)\end{array}$ & $\begin{array}{l}\text { Earliest } \\
\text { statute }\end{array}$ & $\begin{array}{c}\text { Legal } \\
\text { Protection / } \\
\text { WC Benefit } \\
\text { to Employer }\end{array}$ & $\begin{array}{c}\text { Additional } \\
\text { mandatory, } \\
\text { restricted, } \\
\text { or } \\
\text { prohibited } \\
\text { testing } \\
\end{array}$ & $\begin{array}{l}\text { Any form } \\
\text { of drug } \\
\text { testing }\end{array}$ & $\begin{array}{l}\text { Drug } \\
\text { testing as } \\
\text { part of } \\
\text { hiring }\end{array}$ & $\begin{array}{c}\text { Random } \\
\text { drug } \\
\text { testing }\end{array}$ \\
\hline US & & & & 44.6 & 38.9 & 26.4 \\
\hline \multicolumn{7}{|c|}{ Pro-Testing States } \\
\hline Alabama & 1996 & $\mathrm{Y}$ & M & 58.1 & 51.5 & 44.3 \\
\hline Alaska & 2002 & $\mathrm{Y}$ & & 44.9 & 34.2 & 31.4 \\
\hline Arizona & 1995 & $\mathrm{Y}$ & & 52.6 & 46.5 & 32.9 \\
\hline Arkansas & 2002 & $\mathrm{Y}$ & M & 53.9 & 48.5 & 35.1 \\
\hline Florida & 2000 & $\mathrm{Y}$ & M & 51.9 & 45.6 & 32 \\
\hline Georgia & 1998 & $\mathrm{Y}$ & M & 50.1 & 43 & 31.4 \\
\hline Idaho & 1999 & $\mathrm{Y}$ & & 42.9 & 31.7 & 27.6 \\
\hline Iowa & 1996 & $\mathrm{Y}$ & $\mathrm{P}$ & 39 & 33.9 & 23.4 \\
\hline Louisiana & 2003 & $\mathrm{Y}$ & & 56.5 & 50.3 & 42.7 \\
\hline Mississippi & 1999 & $\mathrm{Y}$ & $\mathrm{R}$ & 55.5 & 49.8 & 41.2 \\
\hline Ohio & 2001 & $\mathrm{Y}$ & M & 50.8 & 44.8 & 29.2 \\
\hline South Carolina & 1985 & $\mathrm{Y}$ & M & 50.6 & 46.2 & 34.4 \\
\hline Tennessee & 1999 & $\mathrm{Y}$ & $\mathrm{M}$ & 52.7 & 45.5 & 32.7 \\
\hline Utah & 2001 & $\mathrm{Y}$ & & 49.2 & 38.3 & 30.8 \\
\hline \multicolumn{7}{|c|}{ Anti-testing States } \\
\hline Connecticut & 1996 & & $\mathrm{P}$ & 42.6 & 38.9 & 22.6 \\
\hline Maine & 2001 & & $\mathrm{R}$ & 25.6 & 20.4 & 17.2 \\
\hline Minnesota & 1993 & & $\mathrm{R}$ & 39.8 & 33.4 & 19.2 \\
\hline Montana & 2005 & & $\mathrm{R}$ & 26.2 & 20 & 18.6 \\
\hline Oklahoma & 1999 & & $\mathrm{R}$ & 46.5 & 37.8 & 35.3 \\
\hline Rhode Island & 2003 & & $\mathrm{P}$ & 29.6 & 25.2 & 14.1 \\
\hline Vermont & 2003 & & $\mathrm{P}$ & 17.3 & 11.4 & 9 \\
\hline \multicolumn{7}{|c|}{$\begin{array}{l}\text { Unclassified States } \\
\text { Omitted for space. Available upon requ }\end{array}$} \\
\hline \multicolumn{7}{|c|}{ Cross-state Averages, Unweighted } \\
\hline All Pro-testing & & & & 50.6 & 43.6 & 33.5 \\
\hline All Anti-testing & & & & 32.5 & 26.7 & 19.4 \\
\hline All Unclassified & & & & 42.6 & 36.7 & 25.0 \\
\hline
\end{tabular}

Notes: Source for columns 2-4: DeBernardo and Nieman (2006). M=some testing mandatory; $\mathrm{R}=$ some testing restricted but none prohibited; $\mathrm{P}=$ some testing prohibited. Source for columns 5-7: SAMHSA, Office of Applied Studies, National Survey on Drug Use and Health, 2002 and 2003. Tabulated at special request by the author. Cells are state averages of employed respondents answering affirmatively to a question on whether their employer conducts the listed form of testing in the 2002 and 2003 waves of the NSDUH. Respondents who indicate that their workplace does not test for either alcohol or drug use are legitimately routed out of the questions pertaining to testing during the hiring process or random testing. For this analysis these respondents are classified as being employed by workplaces that do not implement these practices. 


\section{Note on DeBernardo and Nieman classification of state policies:}

A state is considered to be pro drug testing if an employer that implements drug testing procedures in that state either receives a discount on workers' compensation premiums or receives legal protection. For example, the state of Alabama provides a five-percent discount on workers' compensation premiums to employers which implement a drug testing program. Under this program, if an employee has caused or contributed to an on-the-job injury, then a drug test is mandatory. An employee who tests positive will be ineligible to receive any workers' compensation. An example of legal protection is provided by the state of Mississippi. Mississippi passed legislation which absolves an employer which implemented a drug testing program from civil liability. An employee cannot bring a case for defamation, libel, or slander against an employer that complied with the drug testing legislation. The following fourteen states are considered pro drug testing.

A state is considered to be anti-drug testing if the state restricts or prohibits drug testing in any of the following procedures: job applicant testing, random testing, reasonable suspicion / for-cause testing, periodic announced testing, and post-accident testing. For example, the state of Montana restricts job applicant testing to jobs in hazardous work environments, fiduciary or security positions, and positions that could affect public safety. Vermont and Rhode Island prohibit random drug testing and even periodic announced drug testing. Seven states are considered anti-drug testing states. Iowa and Mississippi are two states that are considered as pro drug testing states even though they have restrictions on drug testing. In Iowa, random drug testing must be selected by an entity independent of the employer and by using a computer procedure. Post-accident drug testing is only permitted with a serious injury or property damage in excess of $\$ 1,000$. In Mississippi, job applicants must be provided with a written notice of drug testing upon application and random testing is permitted on a "neutral selection" basis. 


\section{APPENDIX I: Drug Testing and Drug Use Details}

Drug testing differs from other forms of employer screening and monitoring in that it requires the collection and analysis of a physical specimen. In most cases, this involves the collection of a urine specimen by a third party within a specified time frame after receiving a job offer or testing notice. ${ }^{30}$ The most common testing kits screen for 5 to 10 different types of drugs, including the active ingredients in prescription painkillers. Contrary to some popular claims, drug screening has a low rate of false positives - about $2 \%$ or less. A bigger concern for employers is the rate of false negatives in the screening phase. While it is true that an industry has evolved to help individuals pass drug tests, the main threats to test validity are high rates of false negatives that occur even in the absence of evasion efforts by tested individuals. ${ }^{31}$ False negative rates average $20 \%$ over the five main drug classes but are highest for marijuana-over 40\% (U.S. Department of Justice, 1991). A large number of false negatives are also due to generous cutoff levels established by the National Institutes on Drug Abuse rather than to technological limitations in the screening methods (National Research Council, 1994 Ch. 3). A final source of false negatives is lax oversight in testing facilities which enables cheating when testing protocols are not followed (Government Accountability Office, 2007).

Table A2 summarizes patterns of drug use in the U.S. population aged 18 to 55. Use rates for all groups were stable or declining over the 1990s but increasing since 2000. This is clear in the decade-level averages in Table 2. Despite these long-run trends, there are stable differences in drug use across demographic groups and drug classes. First, marijuana use is much more common than other drug use, but group differences in marijuana use tend to be mirrored in the use of other drugs. The biggest group difference in use rates is across genders: men use drugs at nearly double the rate for women. The other major group difference is across ages. Individuals aged 18-25 are more than twice as likely as those 26-55 to have used drugs in the past month. Racial and ethnic differences in use rates are not nearly as large, with blacks and whites using at roughly equal rates and Hispanics at somewhat lower rates, especially for marijuana. Finally, drug use is also more common among the less educated, in this case, those with no post-secondary education. ${ }^{32}$

I also create mutually exclusive groups based on multiple demographic characteristics.

Employers likely see their applicants and employees as a collection of traits, e.g. "black male with a high school diploma," rather than evaluating their likelihood of drug use based on their characteristics separately. Accordingly, I group NSDUH respondents into gender/race (black or white)/skill cells. Hispanics are excluded, and I did not group on age since between the ages of 18 and 65 , the age distribution is fairly similar across races. The bottom panel of Table A2 shows use rates for these eight groups. Consistent with the results in the top panel, I find that within gender and skill cells, blacks and whites use drugs at similar rates. If anything, blacks use at lower rates than

\footnotetext{
${ }^{30}$ Drug tests using other specimens, including blood and hair, are available but almost all employers use urinalysis as their mode of testing. Many employers outsource this collection and analysis to third party firms, but some larger employers have in-house medical departments who conduct the tests.

${ }^{31}$ Most efforts to substitute a urine specimen or to supply one that has been adulterated in order to conceal drug use could be easily detected by monitors at the collection site. (National Research Council, Ch.6, 1994.)

32 Although the NSDUH is the best available source on drug use in a nationally representative population, there is considerable evidence that drug use is underreported in survey data (Mensch and Kandel 1988; Fendrich and Kim 2002 survey the literature on underreporting in household surveys; Lu et al. 2001 survey the literature on underreporting among institutionalized populations). Lu et al. (2001) find underreporting rates centering on 50\% in a sample of arrestees. They find that underreporting differs somewhat across drug classes, with hard drugs more underreported. Some studies have found disparate rates of underreporting across races but these go in both directions (Lu et al. 2001). 
whites in the same categories. The exception is marijuana use in the 1980s, but this is not apparent in the larger and more extensive samples of the 1990s and 2000s. ${ }^{33}$

Appendix Table A2: Drug Use Rates by Group and Decade

\begin{tabular}{|c|c|c|c|c|c|c|}
\hline \multirow[t]{2}{*}{ Past month drug use: } & \multirow{2}{*}{$\begin{array}{c}\text { Any } \\
\text { 1990-2006 } \\
\text { Average } \\
\end{array}$} & \multicolumn{3}{|c|}{ Marijuana } & \multicolumn{2}{|c|}{ Other Drugs } \\
\hline & & $1980 \mathrm{~s}$ & $1990 \mathrm{~s}$ & $2000 s$ & $1990 \mathrm{~s}$ & $2000 \mathrm{~s}$ \\
\hline \multicolumn{7}{|c|}{ Basic Demographic Groups } \\
\hline Whites & 0.13 & 0.12 & 0.087 & 0.11 & 0.044 & 0.059 \\
\hline Blacks & 0.12 & 0.17 & 0.091 & 0.12 & 0.034 & 0.038 \\
\hline Hispanic & 0.086 & 0.095 & 0.053 & 0.075 & 0.035 & 0.048 \\
\hline Other race & 0.11 & 0.16 & 0.065 & 0.10 & 0.035 & 0.05 \\
\hline Women & 0.091 & 0.10 & 0.055 & 0.08 & 0.031 & 0.045 \\
\hline Men & 0.15 & 0.20 & 0.11 & 0.14 & 0.05 & 0.065 \\
\hline Ages 18-25 & 0.17 & 0.24 & 0.12 & 0.16 & 0.055 & 0.077 \\
\hline Ages 26-55 & 0.07 & 0.091 & 0.052 & 0.054 & 0.029 & 0.031 \\
\hline No Post-secondary & 0.13 & 0.14 & 0.088 & 0.12 & 0.046 & 0.063 \\
\hline Some Post-second. & 0.10 & 0.15 & 0.066 & 0.094 & 0.031 & 0.046 \\
\hline \multicolumn{7}{|c|}{ Selected Mutually Exclusive Groups } \\
\hline LS Black Men & 0.19 & 0.24 & 0.15 & 0.19 & 0.053 & 0.051 \\
\hline HS Black Men & 0.13 & 0.24 & 0.095 & 0.13 & 0.03 & 0.034 \\
\hline LS Black Women & 0.10 & 0.12 & 0.077 & 0.097 & 0.031 & 0.04 \\
\hline HS Black Women & 0.07 & 0.13 & 0.042 & 0.063 & 0.02 & 0.023 \\
\hline LS White Men & 0.19 & 0.17 & 0.14 & 0.17 & 0.069 & 0.084 \\
\hline HS White Men & 0.14 & 0.16 & 0.099 & 0.12 & 0.043 & 0.058 \\
\hline LS White Women & 0.11 & 0.098 & 0.07 & 0.097 & 0.043 & 0.058 \\
\hline HS White Women & 0.088 & 0.084 & 0.054 & 0.077 & 0.027 & 0.042 \\
\hline
\end{tabular}

Notes: Data are from National Survey on Drug Use and Health (NSDUH), survey years 1979, 1982, 1985, 1988, 19902006. Total observations in 1980s (which includes 1979) equals 18,903; in 1990s equals 163,079; and in 2000s equals 246,889 . Prior to 1990 , non-marijuana drug use was only asked for selected drugs by name. Race categories exclude Hispanics. Sample is unweighted.

33 Prior to 1987, the NSDUH was conducted at intervals of several years and sampled a much smaller number of individuals than in later years. This is reflected in the total observations reported in the table notes. 


\section{APPENDIX II: Robustness Checks}

\section{APPENDIX Table A3: Comparison of pro-testing legislation impacts across models}

\begin{tabular}{|c|c|c|c|c|c|}
\hline Specification: & [1] & [2] & [3] & [4] & [5] \\
\hline Black x Pro & $\begin{array}{c}0.017 \\
(0.013)\end{array}$ & $\begin{array}{l}0.005 \\
(0.01)\end{array}$ & $\begin{array}{l}0.016 \\
(0.01)\end{array}$ & $\begin{array}{l}0.016 \\
(0.01)\end{array}$ & $\begin{array}{c}0.015 \\
(0.012)\end{array}$ \\
\hline Hispanic x Pro & $\begin{array}{l}-0.016 \\
(0.011)\end{array}$ & $\begin{array}{c}-0.032 \\
(0.009)^{* * *}\end{array}$ & $\begin{array}{l}-0.01 \\
(0.01)\end{array}$ & $\begin{array}{c}-0.008 \\
(0.01)\end{array}$ & $\begin{array}{l}0.005 \\
(0.01)\end{array}$ \\
\hline Female x Pro & $\begin{array}{c}0.005 \\
(0.013)\end{array}$ & $\begin{array}{c}0.005 \\
(0.008)\end{array}$ & $\begin{array}{c}-0.018 \\
(0.008) *\end{array}$ & $\begin{array}{l}-0.016 \\
(0.008)\end{array}$ & $\begin{array}{l}-0.015 \\
(0.008)\end{array}$ \\
\hline Age $18-25$ x Pro & $\begin{array}{l}-0.004 \\
(0.008)\end{array}$ & $\begin{array}{l}-0.011 \\
(0.007)\end{array}$ & $\begin{array}{l}-0.009 \\
(0.007)\end{array}$ & $\begin{array}{l}-0.01 \\
(0.007)\end{array}$ & $\begin{array}{c}-0.01 \\
(0.008)\end{array}$ \\
\hline Low Skill x Pro & $\begin{array}{c}-0.01 \\
(0.015)\end{array}$ & $\begin{array}{c}-0.028 \\
(0.005)^{* * *}\end{array}$ & $\begin{array}{c}0.01 \\
(0.006)\end{array}$ & $\begin{array}{c}0.008 \\
(0.006)\end{array}$ & $\begin{array}{c}0.012 \\
(0.006)\end{array}$ \\
\hline Pro-testing Law & $\begin{array}{c}0.00 \\
(0.009)\end{array}$ & $\begin{array}{l}0.012 \\
(0.01)\end{array}$ & $\begin{array}{l}-0.002 \\
(0.009)\end{array}$ & $\begin{array}{l}-0.008 \\
(0.009)\end{array}$ & $\begin{array}{l}-0.003 \\
(0.009)\end{array}$ \\
\hline State level controls & State FE & $\begin{array}{l}\text { Group x } \\
\text { State FE }\end{array}$ & $\begin{array}{l}\text { Group x } \\
\text { State FE }\end{array}$ & $\begin{array}{l}\text { Group x } \\
\text { State FE }\end{array}$ & $\begin{array}{l}\text { Group x } \\
\text { State FE }\end{array}$ \\
\hline Year level controls & Year FE & Year FE & $\begin{array}{l}\text { Group x } \\
\text { Year FE }\end{array}$ & $\begin{array}{c}\text { Group x } \\
\text { cubic } \\
\text { trends }\end{array}$ & $\begin{array}{c}\text { Group x } \\
\text { cubic trends }\end{array}$ \\
\hline $\begin{array}{l}\text { Time-varying state } \\
\text { controls }\end{array}$ & $\begin{array}{c}\text { Linear state } \\
\text { trends }\end{array}$ & $\begin{array}{l}\text { Linear state } \\
\text { trends }\end{array}$ & $\begin{array}{l}\text { Cubic state } \\
\text { trends }\end{array}$ & $\begin{array}{l}\text { Cubic state } \\
\text { trends }\end{array}$ & $\begin{array}{l}\text { Cubic state } \\
\text { trends and } \\
\text { state UR, } \\
\text { min wage, \& } \\
\text { incarceration } \\
\text { rate }\end{array}$ \\
\hline R-squared & 0.058 & 0.064 & 0.065 & 0.065 & 0.063 \\
\hline $\mathrm{N}$ & 2096833 & 2096833 & 2096833 & 2096833 & 1603993 \\
\hline
\end{tabular}

Notes: Data are from March CPS 1980-2010. All specifications include a full set of demographic group main effects: dummies for black, Hispanic, female, and low skill status as well as age and age squared. Coefficients on the main effects are similar across specifications. State incarceration rate data was only available through 2006, reducing $\mathrm{N}$ in [5].

\section{Discussion of Table A3}

Column 1 of Table A3 estimates Equation 5. Column 2 allows the state fixed effects in (5) to differ across demographic groups, and Column 3 extends this to the year fixed effects while also making the state trends more flexible. Column 4 is the preferred specification, Equation 7 . It substitutes cubic groups-specific time trends for group-specific year fixed effects. Finally, Column 5 adds the state-year characteristics as controls to the preferred specification.

The first thing to notice in Table A3 is that the coefficients on the black x Pro interaction are largely robust across specifications. Coefficients on other interaction terms, however, are not. 
Comparing the estimates in Columns 1 and 2 to those in Column 3 shows that the demographic group interactions with pro-testing laws reverse sign or dramatically change magnitudes for most groups in going from the specification in [2] to that in [3]. In unreported results, I observed that this is largely due to the inclusion of group-specific year effects rather than the switch from linear to cubic state trends. Once this change is made, moving from the specification in [3] to those in [4] and [5] has little impact on the coefficient estimates.

\section{APPENDIX Table A4: Robustness analysis using later sample periods}

Panel (i): Data restricted to 1990-2010

\begin{tabular}{lccccc}
\hline $\begin{array}{l}\text { Dependent } \\
\text { Variable: }\end{array}$ & Employed & $\begin{array}{c}\text { High Test } \\
\text { Ind. }\end{array}$ & $\begin{array}{c}\text { Employed in } \\
\text { Large Firm }\end{array}$ & $\begin{array}{c}\text { Health or } \\
\text { Pension }\end{array}$ & $\begin{array}{c}\text { Log Real } \\
\text { Hourly Wage }\end{array}$ \\
\hline $\begin{array}{l}\text { Effect Size: LSBM x } \\
\text { Pro - LSBM x Anti }\end{array}$ & -0.004 & 0.043 & 0.117 & -0.017 & 0.07 \\
\hline $\begin{array}{l}\mathrm{H}_{0} \text { : LSBM x Pro }= \\
\text { LSBM x Anti (p-val) }\end{array}$ & 0.91 & 0.21 & 0.002 & 0.60 & 0.23 \\
\hline $\mathrm{N}$ & 1653170 & 1276674 & 1395511 & 1395511 & 1227509 \\
\hline
\end{tabular}

Notes: Identical to Table 7 with the exception that CPS years 1980 to 1989 are excluded from the analysis. 


\section{APPENDIX III: Theory Details}

\section{Detailed Discussions}

\section{On why one sector and not the other would adopt testing:}

If testing sector firms have market power while the non-testing sector is perfectly competitive, this can provide a rationale for the adoption of testing in the former. Firms with market power make some positive profits from each non-using worker and would therefore like to screen out drug users, from whom it is assumed they make zero or negative profits. Assuming that testing sector firms have market power would not substantively alter the conclusions of the model and would be consistent with the evidence on firm size and industry mix of testing versus non-testing firms in Table 1.

On the assumption that $D_{i}=1$ leads to zero productivity:

This simplification is similar to a more general specification: $s_{T}\left(D_{i}\right)=s_{T}-D_{i} f\left(s_{T}\right)$ where $f^{\prime}>0, f^{\prime \prime}>0, \lim _{\mu \rightarrow-\infty} f=0$, and $\lim _{\mu \rightarrow \infty} f=\infty$. In both cases the absolute productivity loss from drug use is larger for more able individuals and becomes negligible toward the very bottom of the productivity distribution. It is also similar to assuming that drug use is associated with a small probability of a large productivity loss such as that caused by a serious workplace accident or a large theft from the firm, which could be expressed $s_{T}=s_{T}+D_{i} * \varepsilon *$ loss.

\section{On the assumption that $D_{i}$ is independent of $\boldsymbol{s}$ :}

The limited evidence available suggests that detecting drug use from information other than drug tests is extremely difficult. Other methods of ascertaining drug use among job applicants without resorting to drug tests (e.g. using detailed personality testing targeted to detect drug use) have been found to have fairly low correlations with actual use and high rates of false positives (National Research Council, Ch. 6, 1994). If drug use were closely related to underlying skills, we might expect alternative methods of detecting it to prove more useful. Also, the Conference Board study reports that supervisors are commonly advised not to try to guess at drug use among their employees but rather to look for specific changes in performance before ordering testing (Conference Board, 1990).

On the claim that the probability of drug use among hired workers is lower after testing is introduced, i.e. $\widetilde{p}<p$ :

Assume detection is independent of $\mathbf{s}$ within the tested population, and that a constant fraction $\delta$ of users is detected by the tests. For any population with a fixed use rate, increasing the probability of detection has an unambiguously negative effect on the probability that a hired worker is a drug user. To see this, let $\mathrm{N}_{0}$ denote the number of non-users in the population; $\mathrm{N}_{1}$ is the number of users. For $\delta, \delta^{\prime} \in[0,1]$ and $(\delta)=(1-\delta) N_{1} / N_{0}+(1-\delta) N_{1}$, simple algebra shows that $p(\delta)>$

$p\left(\delta^{\prime}\right) \forall \delta<\delta^{\prime}$, which would imply $p>\tilde{p}$. Hence $p_{M i}>\tilde{p}_{M i} \forall i=0,1 .^{34}$ Thus precision in selecting

\footnotetext{
${ }^{34}$ It is possible that changes in drug use rates or changes in the composition of the sectoral applicant pool may change the drug use rate in this population such that $p<\tilde{p}$. I discuss this possibility in the Theory Appendix.
} 
non-users from among the same pool of workers increases under testing, as asserted in the main text.

Note that higher post-testing wages may attract more users to the testing sector since they still have a positive probability of evading detection. In this case, I assume firms will correctly evaluate the overall use rates in their workforce via total output even if they cannot detect individual drug use with certainty. They will therefore adjust wages downward when faced with higher shares of users in their workforce, which will in turn lower the share of users attempting to work in the sector. In this way, a new post-testing equilibrium share of users in the labor supply to the testing sector is maintained.

In principle, one could look for changes in wage structures across the two sectors following the introduction of testing in order to assess whether productivity changed in the testing sector relative to the non-testing sector. (I have done this, and the results are available upon request.) However, this exercise would not map directly into predictions of the model without further assumptions. Even with the assumption of log normality in wages, the Roy model is unable to generate unambiguous predictions the mean and variance of log wages within sectors and demographic groups. The ambiguous effect of a single-sector price change on these quantities is apparent in the formulas for them provided in Heckman and Sedlacek (1985). In the standard model, additional assumptions are required about the covariance of the disturbance terms to generate clear predictions. The ambiguity is compounded in the drug testing setting because the price change induced by testing is not equal across the using and non-using segments of the population, and therefore even the size of the testing sector is unclear without additional assumptions about how the skill price change and detection jointly affect the sector choices of drug users.

\section{$C D F$ for $\operatorname{Pr}(T)$ :}

Abstracting from demographic group differences, the assumption of log normality implies that the probability of employment in the testing sector for non-users is the following (Heckman and Sedlacek, 1985):

$$
\begin{aligned}
& \operatorname{Pr}(T)=\operatorname{Pr}\left(\ln w_{T} \geq \ln w_{N}\right)=\Phi\left(c_{T}\right) \\
& \text { where } c_{T}=\frac{\left(\ln \frac{\pi_{T}(p)}{\pi_{N}}+\mu_{T}-\mu_{N}\right)}{\sigma^{*}} \text { and } \sigma^{*}=\sqrt{\operatorname{var}\left(\varepsilon_{T}-\varepsilon_{N}\right)}
\end{aligned}
$$

